\title{
CONCEPTS AND POLICIES IN ANGLO-AMERICAN ADMINISTRATIVE LAW THEORY
}

\author{
By RALPH F. FUCHS †
}

\section{Administration and Administrative Law in Relation To DeMOCRACY}

MUCH WATER has run over the dam since, in the last decades of the nineteenth century, Anglo-American legal writers began to concern themselves with the previously undiscussed topic of administrative law. Monographs, small treatises, and upward of 20,000 pages of periodical literature have dealt with the subject, but the multiplication of administrative agencies of government, especially during and since the Great War, has far outrun the ability of students and commentators to keep up with it. Recurrent political movements for remedying by governmental action the evils of an industrial era have left deposits of regulatory and welfare legislation which have engendered opposition to growing public expenditures and to interference with private activity, particularly that of business enterprise. Stirred by such opposition or by a concern for governmental efficiency in the face of a mounting administrative burden, public and private committees and commissions in both England and the United States have investigated and reported upon proposals for simplifying the official structure and improving the procedure of especially those agencies which deal with private persons and property.

Modern life has, however, continued apace its headlong pursuit of technological advance despite the increasing governmental problems which are created by it. At the same time the world of man has largely ceased to expand geographically; opportunity for all must now be carved out at home. Basically, of course, the problems created by technology and by the disappearance of frontiers are not legal and administrative but economic and political. ${ }^{1}$ They arise not only from the increased tempo of life and an expanded population in a limited area, but still more from the inadequacy of the prevailing institutions of management and control. The system of mass production, for example, as often has been said, requires cooperation among large groups of producers and full par-

†Professor of Law, Washington University; Fellow, Columbia Univer!ıty School of Law, 1937-38.

1. It is recognized, of course, that the final problems in government as in other fields of endeavor are philosophical, relating to the ultimate ends of life. But it is not necessary to revert to the primary purpose of the state in a discussion which assumcs the democratic thesis and, hence, a common purpose that embraces the more limited objectives to which reference is made. See McKechnie, The State and the Individual (1896) 89. 
ticipation in its benefits by the mass of consumers; yet management is still to a great extent in the hands of a limited number of property owners, whom labor unions recurrently challenge. The system, too, is obviously international; yet nationalist authorities exercise sovereign control with an eye partly to war. Hence the difficulties to be solved are not merely those of coordinating the participating elements in a common life, but the far greater ones of bringing warring groups together and checking the power of vested interests that do not coincide with the general interest.

Increased urgency in the problems to be met has naturally called forth more drastic governmental measures for dealing with them. Dictatorships have arisen to challenge democracies as instruments for solving these problems, and a burning issue in the so-called democratic nations is whether this challenge can be met. Important in resolving that issue is the sufficiency of the systems of administration which have been the chief reliance of these nations for (1) achieving justice in ordinary human relations, (2) carrying on the growing volume of day-to-day public services, (3) collecting taxes, and (4) adjusting those clashes of group interest which have been engendered by maladjustment between the scope of the problems to be met and the competence of the agencies relied upon for dealing with them. The fourth of these tasks of administration may, if one likes, be viewed as temporary, until such time as a better distribution of power is achieved. Even after that much-to-be desired outcome has been attained, however, the need for public administration will be greater than it has been until recently, for the increased magnitude and tempo of the activities produced by technological advance will be relatively permanent. Those qualities of current democratic administration which are pertinent to democracy, therefore, will be important as long as the governments which are able to make use of them endure, whether these governments be capitalist or socialist in nature; and the deficiencies will be equally harmful to either type of organization. $^{2}$

There is an important distinction between administration and administrative law. Administration embraces the entire conduct of governmental activity, aside from the actual formulation of fundamental policy. It includes the application of law and the piecemeal determination of policy through judicial decision; as well as the more ordinary activity of the executive branch of the government and the routine operations

2. Cf. Sharfman, The Interstate Commerce Commission: an Aspraisal (1937) 46 Y ALE L. J. 915, at 954. It is true, of course, that the qualities of democratic administration which relate merely to efficiency will be of value to any type of government, democratic or other, which is in a position to make use of them. For the purposes of this discussion, however, they are of importance only in so far as they coexist with qualities which are democratic. 
of the other two branches. For historical reasons, however, the deciding of cases by the courts has usually been excluded from the concept of administration. In accordance with the above definition, moreover, a distinction is drawn between executive action of major importance in policy determination and the day-to-day activities of executive agencies, which are spoken of as administration. ${ }^{3}$

In one sense the term administrative law embraces all the law that controls, or is intended to control, the administrative operations of government. It includes the law which provides the structure of goverament and prescribes its procedure, ${ }^{4}$ but not the substantive law which administration is supposed to apply, nor, of course, the policies of executive and legislature in major matters of statecraft. It embraces the law which governs the methods of legislatures, provides for the existence and operation of the courts aside from their procedure in the actual progress of litigation, establishes the executive agencies and governs their procedure, and determines personnel policies in all branches of the government. Lawyers' administrative law, however, is a considerably narrower concept. Roughly speaking, it embraces the law which is pertinent to the bearing of administration upon private persons and property. Because those aspects of government in which it bears upon individuals and their property have always been of central significance in democratic theory, lawyers' administrative law is of crucial importance in relation to the adaptation of democratic administration to contemporary demands.

There is another and perhaps more fundamental side to democratic theory - the affirmative side, which has to do with the representation of individuals and interests in government and their participation in the formulation of policy and with the effectuation of policies when arrived at. The legal phases of this aspect of democracy, however, have not been especially important, and, moreover, the problems which have arisen in this field have not given rise on the whole to basic controversy. Since

3. The essay by Professar Fairlie, Origin and Meaning of Public Administration, which opens the volume of Essays on the Law and Practice of Governmental Administration in Memory of Frank J. Goodnow (1935), contains an excellent review of the various conceptions of administration that have been entertained from time to time.

4. Viewed in this light, it embraces much of constitutional law. Berle, The Expansion of American Administrative Law (1917) 30 HARv. L. REv. 430. Conventionally, however, that portion of the law of administration which receives expression in constitutional provisions is segregated in a constitutional law which is thought of as superior to the administrative law that ordinarily goes by that term.

5. It is not intended to insist that there is a hard-and-fast distinction between procedural law and substantive law. Thus, the law of the valuation of public utilitics may be stated in part as the obligation of the regulating agency to take account of specified data. But here, as in court-administered law, there is on the whole an obvious difference between the rules governing notice, hearing, etc., in the proceedings of administrative agencies and the content of the orders which issue from them. 
the removal of property qualifications for voting and the enfranchisement of women, the protection of the right of subject races, such as the negroes, to participation in government has presented the principal difficulty in this connection. The issue of group representation in the legislature has not been pressed. Similar problems of representation arise in industry; but when the democratization of the economic order is sought, the government's relation to that effort raises questions of the bearing of administration upon private persons and property, and, consequently, the sphere of lawyers' administrative law is entered. Within the past two years, however, proposals in this country for reorganizing the executive branch of the Federal Government have brought the affirmative side of democratic theory to the fore, especially with regard to its implications and effects upon lawyers' administrative law.

The reasons for the importance of the bearing of government upon private persons and property in Anglo-American democratic theory are not far to seek. First is the fact that democratic government arose out of protest against the oppressions and abuses of existing governments. Hence the emphasis upon the security of private interests in the political theory of John Locke ${ }^{8}$ and in the Bills of Rights. These, in part, gave legal expression to the popular victories in the English and American revolutions-for distrust of old governments did not easily give way to confidence in the new. ${ }^{\top}$ Secondly, the rise of democratic government coincided with the increasing sway of the laissez-faire economic theory that responded to the needs of a commercial age. Locke, Adam Smith, Blackstone, Bentham, and Jefferson voiced the dominant political, economic, and legal theories of their time. The last four were contemporary with each other and with the American Revolution, and laissez-faire was woven into the fabric of their thought. ${ }^{8}$ From their thinking derives the Anglo-American norm of the "capitalist-constable" state."

The theory of the separation of powers, ${ }^{10}$ the specific provisions of the English, Federal, and American state bills of rights, and the limitations which have been read into the due process clauses of the Fifth and Fourteenth Amendments, ${ }^{11}$ constitute the main body of legal doctrine expressing the keen distrust of political authority over private per-

6. Cf. Hamilton, Property-According to Locke (1932) 41 YALE L. J. 854.

7. The story of the continued emphasis upon legal protection against the government in English history is well told in Dicknison, Adumismatrve Justice aro tae Suprearacy of Law (1927) c. 4.

8. Cf. Walias, The Great Soctety (1920) c 7; Fuchs, The Ncuer Social Scientists Look af Law (1927) 13 ST. Lours L. REv. 33; Franlalin, Administratize Law in the United States (1934) 8 TULANE L. REv. 483.

9. Beard, Individualism and Capitaliom (1930) 1 Excra Soc. Screjices 145, 161.

10. Sharp, The Classical American Doctrine of "The Seforation of Pousers" (1935) 2 U. of Car. I. Rev, 385; Murr, How Brrtars Is Goperswed (1929) 18. 
sons and property that has accompanied the rise of Anglo-American democracy. That distrust, it is true, has operated in the presence of conceded governmental power - power inherited from the absolute monarchy in England and in the states, and power conferred by the Constitution in the case of the Federal Government. But it is the limitations and not the power which, until now, have been the primary concern of the courts, of perhaps most theorists, and of almost all legal writers since 1776. "There is a type of social habit which abhors all official intervention in private affairs," manifesting itself "in a constitution of law and government which confines public functions as far as possible to the exercise of judicial power." 12 Such has been the Anglo-American habit as it has been reported in many a learned piece of writing.

In England the theory of the separation of powers has, of course, been expressive of an ideal and has not been legally enforcible. As a necessary democratic supplement to it in the presence of a hereditary Crown, the doctrine of Parliamentary supremacy has held sway since the time of the Glorious Revolution. ${ }^{18}$ Directed mainly against the executive, its terms have not been altered in legal minds by the rise of the Cabinet and the establishment of ministerial responsibility to Parliament. In the United States a theoretical equality in rank has continued to prevail among the three departments of government.

Against this background, it is small cause for wonder that the enormous expansion of governmental administration affecting private persons and property should have created consternation in the legal world. The facts regarding the expansion of administrative powers during the past fifty years are too familiar to require presentation here. ${ }^{14}$ The net result is

11. Motr, Due Process of LAw (1926) Part V. Specific provisions of the main body of the Federal Constitution, such as the contract clause, might also be mentioned. They are, however, of less contemporary importance than those included in the text.

12. Freund, The Growth of Ambrican Aduinistrative Law (1923) at 17.

13. $1 \mathrm{BL}$. Coмm. *54; Rutledge, Legal Personality-Legislative or Judicial Prerogative (1929) 14 St. Lours L. REv. 343, at 367-369.

14. Good historical summaries of the English development will be found in Anderson, Bureaucracy (1929) 7 J. PUB. Ads. 3; MUIR, How BrITAIN Is Governed (1929) 44-54; Stamp, Recent Tendencies Towards the Devolution of Legislative Functions to the Administration (1924) 2 J. Pub. Admin. 23; Willis, The Parlinzasentamy Powerg of Engliśn Governanent Departurents (1933) 17-46. The statistics of delegated rule-making in England are given in the testimony of $\mathrm{Mr}$. Cecil $\mathrm{T}$. Carr before the Committee on Ministers' Powers [Mnnures of Evid. (1932) at 204]. For the United States, descriptive summaries are contained in Bevis, Administrative Commissions and the Administration of Justice (1928) 2 U. of CIN. L. REv. 1; Shepherd, Legal Controls through Administrative Law (1934) 14 ORE L. REv. 67; C. Pound, Constitutional Aspects of American Administrative Law, in THE Growtr of Amexrcarr AdasinistraTIVE LAw (1923), reprinted in (1923) 9 A. B. A. J. 409. For summaries which include the New Deal developments see Brachly \& Oatman, Adarinistzattve Legrslatron AND Adjudication (1934); American Bar Association, Report of the Special Com- 
that numerous public officials ${ }^{15}$ exercise licensing, rule-making, and deciding powers over many forms of private activity and minister to some of the most fundamental needs of the entire population, such as educition, health, and old-age security. Although most of these officials are in the executive branch of the government, many of their functions are indistinguishable in nature from those performed by the legislature and by the courts. The controls over the acts of the administration, moreover, exercised by the legislature, by the courts, and by the people themselves, are remote and partial in their operation. Either demosracy has been seriously impaired by the change that has taken place, or else the traditional theories of limitation of governmental power in a democracy are in need of material revision.

\section{Concepts and Policies in Contemporary Theory}

The development of administrative power over private persons and property was generally ignored in Anglo-American legal thought until after it had become an outstanding phenomenon. ${ }^{10}$ Its classic initial recognition in England ${ }^{17}$ consisted of a denial that anything had changed so far as the legal protection of individual rights was concerned, ${ }^{18}$ an opinion which still has its echo in some of the literature. ${ }^{10}$ Such obscurantism, however, has now largely disappeared. Both the desirability of the growth of official power and the proper scope of judicial control over administrative action are subjects of acute controversy.

The thinking on these issues may be said to fall into the twofold classification of conceptual and functional. ${ }^{29}$ According to the conceptual

mittee on Administrative Law (1936) 61 A. B. A. Rep. 720. Fneumd, Adumüsmatme Powers over Persons and Property (1928) contains a thorough analysis of the administrative powers which had been conferred prior to the author's study in England, pre-war Prussia, New York, and the Federal system.

15. Statistical Abstract of the United States (1936) contains statistics of the personnel of the Federal Government and of the proportion of the national income expended by Federal, state, and local governments in the United States.

16. Frankfurter, The Task of Administrative Law (1927) 75 U. OF PA. L. REv. 614.

17. Fairlie, op. cit. supra note 3, at 15-21, recites earlier instances of the recognition of administration as a branch of jurisprudence. Bentham probably is the intellectual founder of the modern British departmental system and of the science of administration. Wallas, Jeremy Bentham (1930) 2 Excyc. Soc. Scr. 518.

18. Dicey, The Law of the Constitution (1885) 177-181. "In England, and in countries which, like the United States, derive their civilization from English sources, the system of administrative law and the very principles upon which it rests are in truth unknown." Id., at 180.

19. Writers cited in Robson, Justice ANd Admmistratrve Law (1928) at 30.

20. Willis, Three Approaches to Adnimistratize Law: The Judiciol, the Conceptual, and the Functional (1935) 1 U. of Toronto L. J. 53. Willis" "judicial" approach is simply that of the judges, motivated by unwillingness to give free scope to the rival administrative power. 
view, the object to be sought is conformity of the methods of administration and their control to assumed ideas about governmental power. In this view, among lawyers, the separation of powers and the supremacy of Parliament, together with the prohibitory constitutional limitations, should be preserved without more than minor modification. ${ }^{21}$ Among political scientists certain norms of governmental organization, supposedly relating to efficiency, are similarly stressed. The functional school of thought envisages as the all-important consideration the adjustment of the machinery of government to the ends which need to be served. From this point of view the question of the proper governmental agency to exercise a given function and of the most desirable form of administrative organization should be answered in terms of the concrete results to be attained-results in both the furtherance of current legislative policy and the protection of private interest. ${ }^{22}$ Functional thinking, of course, does not entirely ignore established categories, but it attaches no weight to their observance in the allocation of governmental functions.

\section{The Role of Discretion in Administration}

Among the questions which have arisen in regard to administrative power over persons and property is that of the degree of discretion which it may involve. One of the most significant theoretical aspects of the action of legislatures is the legally unfettered choice of values, or of ends, which characterizes it. ${ }^{23}$ In this country, it is true, the choices of even the legislature are subject to constitutional limitations, but these, despite their present scope and serious import, operate by way of exception to an otherwise free determination of the policy of statutes. ${ }^{24}$

The execution of statutory policies may or may not require the exercise of further value choices. The determination of facts and the application of the law to them in such situations as tax assessments, the making of compensation awards, and non-discretionary licensing, does

21. "With the practical results of the different position assigned to officials under French and under English law and with the merits or demerits of either system we need not greatly concern ourselves; the one point which should be impressed upon every student is that the droit administratif of France rests upon political principles at variance with the ideas which are embodied in our existing constitution and contradicts modern English convictions as to the rightful supremacy or rule of the law uf the land." Dicey, The Law of the Constitution (1885) 203.

22. "Law is a matter of business; means and ends are the things to be considered in it, not abstractions." MrL, Essay on Bentham in 1 Essays (1865) 397. See McKechnre, op. cit. supra note 1 , at 111,168 ; Willis, supra note 20 , at 75.

23. Freund, Standards of American Legislation (1917) 215-217.

24. Whether in fact the ultimate determination of policy under statutes is by the bodies which apply the statutes rather than by the legislature is a point which does not require consideration here. 
not involve such choices. ${ }^{25}$ The determination of reasonable utility rates, of fitness to pursue an occupation, and of the requirements of public convenience and necessity, on the other hand, does, for the ends to be attained are not fixed and the administrative agencies must make a choice among alternatives. In many situations administration performs a third function. The end is definitely specified, but the measures required to attain it must be gauged by expert judgment. The purchasing power of the income of farmers is to be raised, let us say, to a statistically ascertainable level by means of a system of controlled production, benefit payments, and taxes. Only the expert (if he) can estimate the probable results of the alternative devices and combinations of devices that may be employed to achieve such an end.

Which of these administrative functions should receive the name of discretion is a matter of words. Since the word "discretion" is variously used, it is important to recognize the types of determinations which modern government requires of administrative officers and the sense in which the term is used in particular contexts. Ordinarily it is employed loosely to designate functions of the second and third types just mentioned.

Administrative discretion is exercised in connection with two classes of administrative acts: the laying down of general rules to govern future conduct, analogous to the rules contained in most acts of the legislature; and the making of orders or decisions in particular cases, such as orders for the abatement of nuisances or the granting or refusal of licenses. To distinguish in borderline instances, such as rate-fixing orders, between general rules and orders of specific application is a matter of some difficulty, if not an impossibility. ${ }^{26}$ The mental processes may be the same, moreover, in the formulation of the two types of governmental regulation. $^{27}$ But, on the whole, the classification of regulations into general rules and orders in particular cases is sufficiently clear. These categories,

25. The oft-repeated statement that all administrative action involves some exercise of discretion is highly questionable. Thus, it is not true that the policeman in maling arrests and the marriage license clerk in issuing licenses exercise discretion because from time to time they have difficult fact determinations to malse. Their vorl: involves the exercise of discrimination but not the estimation of probable consequences of a course of action or the choice of policies. If they waive the requirements of law in particular cases, they do so in the absence of legally-conferred diseretion.

26. Austrn, Jurusprudence (1861) 10-15; Fairlie, The Scfaration of Pouters (1923) 21 MIICH. L. REv. 393, at 424; Alzin, The Concept of Legislation (1936) 21 Iowa L. REv. 713; O'Reilly, The Federal Admisistratite Court Proposal: An Examination of General Principles (1937) 6 Fondrass L. Rev. 365, at 371; Drcinsson, op. cit. supra note 7, at 17-21; FREUND, op. cit. supra note 14, at 15; Cooper, Admirristrotive Justice and the Role of Discretion (1938) 47 Y ALE L. J. 577, 584.

27. Green, Separation of Governmental Powers (1920) 29 YALE I. J. 369. 
in other words, are useful for dealing with the phenomena involved. They are also traditional and will be accepted here. ${ }^{28}$

In respect to the administrative formulation of general rules the isste of how much discretion may be conferred arises in the guise of a challenge to the delegation of legislative power. Although the same issue affects the vesting of administrative power to decide particular cases, ${ }^{29}$ the legal issues more commonly raised in regard to the latter power are, first, whether judicial functions have been conferred unconstitutionally and, second, how far administrative decisions should be subjected to judicial review. Regardless of these several issues, there has emerged a fairly definite realization that where discretionary functions are vested in administrative agencies the discretion is the essence of the administrative process, and its exercise should not be disturbed. ${ }^{80}$ Dean Pound - although not without occasional dissent from his own views probably has emphasized this idea more than any other writer. ${ }^{81}$ His work is especially valuable because it has related discretionary administrative powers to developments within the judicial field itself, such as the rise of juvenile courts. Both are largely the products of the increase in problems of a complex and technical nature, the solution of which requires the intuitive judgments of qualified officers, whose mental operations cannot be reduced to rules. ${ }^{32}$

28. Cf. WILLIs, op. cit. supra note 14 , at 49 .

29. See, e.g., Highland Farms Dairy v. Agnew, 300 U. S. 608 (1937) ; Bourjois, Inc. v. Chapman, 301 U. S. 183 (1937) ; (1927) 15 Calrf. L. Rev. 408; Comment (1915) 15 Col. L. Rev. 63 ; Comment (1929) 43 Harv. L. Rev. 302; (1936) 34 Mrck. L. Rev. 572; Powell, Administrative Exercise of the Police Power-Administrative Orders and Executions (1911) 24 HaRv. L. REv. 333; Sigler, The Problem of Apparently Unguided Administrative Discretion (1934) 19 Sr. Lourg L. Rev. 261.

30. Dickinson, op. cit. supra note 7, at 36; Laski, The Growth of Administralive Discretion (1923) 1 J. РUв. Admin. 92; Gordon, Administrative Tribunals and the Courts (1933) 49 L. Q. Rev. 94; Sharfman, op. cit. supra note 2, at 950 ("Perhaps the Commission's most distinctive characteristic as a tribunal lies in the extensive grants of discretionary power with which it is clothed in connection with all aspects of its labors.") See also, Cooper, supra note 26, at 593 et seq.

31. The Administrative Application of Legal Standards (1919) 44 A. B. A. Rep. 445; Introduction to the Philosophy of Law (1922) c. 3. Some of Dean Pound's other writings reflect his more conservative mood. See Executive Justice (1907) 55 AM. L. Reg. 137; Executive Justice (1914) 14 CoL. L. Rev. 12; The Constitulion: Its Development, Adaptability, and Future (1937) 23 A. B. A. J. 739.

32. From this point of view the late Ernst Freund, one of the great pioneer students of administrative law, was on the whole a dissenter. $O p$. cit. supra note 14, at 97-102. "A comprehensive view of administrative discretion discloses a tendency toward standardization with a small residual margin for flexibility which approximates the inevitable question of fact. The function of discretion would then be not to displace rule but to prepare the way for it. On any other terms administrative discretion would be an anomaly. It would mean thast administrative authorities are superior to courto 


\section{The Fate of the Separation of Powers}

a. The Propriety of Administratize Rule-Making. Constitutional decisions in the United States have made it somewhat difficult for legislation to confer upon administrative authorities the power to lay down discretionary general rules. But not all types of administrative rules are affected by these decisions. There are numerous general regulations, such as those governing the personnel policies of government, altering the administrative organization, or allocating expenditures, which do not bear upon private interests and ordinarily are not called into question in court. ${ }^{33}$. There are others, such as those governing the methods of taxing authorities and service agencies of the government in dealing with the public, which do affect private interests but not with sufficient directness to give rise to constitutional issues. Still others, interpretative of statutory provisions which would be unadministerable without them, are of undoubted constitutionality. ${ }^{34}$ Difficulty is created by regulations directly governing private activity and enforcible by criminal sanctions or by other means of compulsion. The Supreme Court has included in this class the instances in which Congress has vested authority in the President to ascertain facts upon whose existence the entry of specified rules into operation has been made to depend. ${ }^{35}$ The vesting of either type

in their capacity to deal with private rights, or that under modern conditions the public welfare demands personal government instead of government by law." Id., at 102. Freund's writings do not disclose any other basis than a conceptual one for combatting the view that administrative authorities may be superior to courts for some purposes, or that personal government may under some circumstances be a good thing. See also The Substitution of Rule for Discretion in Public Low (1915) 9 A2r. PoL. Scr. REv. 666; Administrative Discretion: $A$ Reply to Dean Wigmore (1925) $19 \mathrm{ILL}$ L. Rev. 663. In dealing with specific situations Freund at times was a 'defender against judicial impairment of difficult administrative fact determinations, if not of administrative discretion. The Right to a Judicial Review in Rate Controzirsies (1921) 27 W. V . L. Q. $20 \%$.

33. In the states, it is true, litigation over public expenditures sometimes tums upon the validity of administrative power to fix their amount or determine their use. State v. Smith, 329 Mo. 1019, 49 S. W. (2d) 74 (1932); Tillotson v. Frohmiller, 271 Pae. 867 (Ariz., 1928). Recently, also, the power of the President to allocate funds under some of the New Deal acts has been called in question. Comment (1937) 50 HNrs. L. REV. 802.

34. The correctness of the interpretations embodied in them is subject to judicial check, but deference is paid to the administrative construction which they express. Houston v. St. Louis Independent Packing Co., 249 U. S. 479 (1919) ; Lynch v. Tilden Co., 265 U. S. 315 (1924); Fawcus Mach. Co. v. United States, 282 U. S. 375 (1931). See also Morrissey v. Commissioner of Internal Revenue (1935) 296 U. S. 344.

35. The various types of rule-making power are discussed in the opinion of Mr. Chief Justice Hughes in Panama Refining Co. v. Ryan, 293 U. S. 383 (1934). The power to find facts in order to determine whether certain rules shall come into effect is properly considered along with the power to prescribe regulations, because fre- 
of power may, if judicial criteria of validity are not adhered to, be declared unconstitutional as a delegation of legislative power.

In England the bestowal of "legislative" powers upon executive departments had been a subject of discussion for some years before it was made one of the two problems that the Committee on Ministers' Powers, in 1930, was created to consider. ${ }^{36}$ An excellent earlier study of the subject $^{37}$ had pointed out the needs which under modern conditions have given rise to the practice of delegating rule-making power. These are: (1) the requirement of greater flexibility in the details of a law than the legislature can supply, in order to meet changing conditions; (2) the need for freeing the legislature from concern with details in the initial consideration of a law, because of the pressure of time upon it and the desirability of careful consideration of the fundamental problems involved; (3) the desirability of expert determination of numerous matters involved in modern legislative schemes such as those affecting housing, health, social security, and public services of many sorts; and (4) the necessity of administrative authority to deal with emergencies, for which the legislature often cannot be summoned and with which its processes are too slow to deal, even when it is in session. ${ }^{38}$ The Committee on Ministers' Powers followed the same views, ${ }^{30}$ taking care,

quently the facts to be found are of an indefinite variety [costs of production at home and abroad under a flexible tariff act, as in the act considered in Hampton \& Co. v. United States, 276 U. S. 394 (1928); unfair practices by importers, calling for the application of increased duties or of embargoes, as in the act involved in $E x$ partc Bakelite Corp., 279 U. S. 438 (1929)] and because in effect the President, to whom such powers have usually been entrusted, cannot be made to move when lie decms it undesirable to do so. Goodnow, Prinćiples of the Administrative Law of the United States (1905) 91-94.

36. The Committee's "Terms of Reference" directed it "to consider the powers exercised by or under the direction of (or by persons or bodies appointed by) Ministers of the Crown by way of (a) delegated legislation and (b) judicial or quasi-judicial decision, and to report what safeguards are desirable or necessary to secure the constitutional principle of the sovereignty of Parliament and the supremacy of the Law." See Report (1932) at v.

37. Carr, Delegated Legislation (1921). See also Amos, The Science or LAW (1894) at 399; Ilbert, Methods OF Legislation (1912) at 146.

38. The same factors have been pointed out in subsequent writings. See, e.g., Stamp, op. cit. supra note 14, at 25. Stamp adds the necessity of local differentiation in the administration of some statutes, which can be achieved by means of administrative regulations, and the disastrous effects that would follow a resort to Parliament for minor amendments to a controversial act, when the entire question of the merits of the measure as a whole might be reopened. On the last point see Christie, The Legislature and Administration (1930) $8 \mathrm{~J}$. Pub. Admin. 367. See also, Port, Administratrve LAW (1929) at 137-145; Keith, Brittsh Constitutional LaW (1931) at 84; 2 ANsort, Law and Custom of tee Constitution (4th ed. by Keith, 1935), at 249.

39. See RePort (1932) at 5, 15-16, 22-23, 51-52. 
however, to point out that the justifications thus enumerated do not extend to "abnormal" types of rule-making power, such as the power to legislate in "matters of princip! $e$ " and the power to impose taxes." The Committee recommended that delegation always be in clear language setting precise limits and that "abnormal" delegation should not be resorted to except in unusual circumstances which the Committee specified."

The distinction between rule-making in matters of principle and subordinate rule-making thus enunciated by the Committee on Ministers' Powers is not dissimilar to the test of constitutionality adopted by the Supreme Court in respect to the delegation of rule-making power by Congress. The requirement that an enactment delegating such power shall contain a "standard" to guide its exercise seems equivalent to a requirement that the legislature itself determine matters of "principle," or fundamental policy. ${ }^{42}$ But no satisfactory criterion of what constitutes a sufficient standard has been developed. ${ }^{13}$ Only recently has it become possible to assert that Congress must indicate both the permissible content of the regulations and the occasions when they may be made. ${ }^{41}$ For either purpose, however, the language employed may be so general as to have the effect of leaving administrative discretion with implied rather than expressed guides. ${ }^{45}$ The chief consequence of statutory standards, therefore, even when they have passed muster from the standpoint of constitutionality, is to furnish an alleged test to be applied in the judicial

40. Id., at 30,31 .

41. Id., at 58-61. The Committee, taking note of considerations suggested by Sir Maurice L. Gwyer, Treasury Solicitor, [MInutes of Evmence (1932) at 2] conceded that even apart from "emergency" situations, rule-maling power which is not in terms limited to matters of detail may properly be conferred for the purpose of enabling a government department to inaugurate a complicated scheme of administration such as that necessitated by the National Insurance Act of $1911,1 \& 2$ GEo. $V, c 55$. It is impossible for Parliament to anticipate many problems that will arise under this bind of measure or to adopt amending legislation when the need arises, especially where the scheme is a controversial one. The Committee thought, however, that such power should be limited to one year following the effective date of an act. For the use made of such power under the National Insurance Act and two subsequent measures see Committee on Ministers' Powers, Miezroranda by Governarent Departaresits (1932) 31-33. Actually, the orders which were issued dealt only with details, but it would have been impossible to anticipate what details would require treatment.

42. Cheadle, The Delegation of Legislative Functions (1918) 27 YALE L. J. 892, at 898.

43. Cousens, The Delegation of Federal Legislative Pouser to Executive Officiols (1935) 33 MIrCH. L. REv. 512.

44. Panama Refining Co. v. Ryan, 293 U. S. 388 (1934) ; Schechter Poultry Corp. v. United States, 295 U. S. 495 (1936); Comment (1935) .48 Harv. I. REv. 809.

45. Cheadle, loc. cit. supra note 42; Cousens, loc. cit. supro note 43; New Yorls Central Securities Corp. v. United States, 287 U. S. 12 (1933). 
review ${ }^{46}$ of rules that purport to follow their directions. ${ }^{47}$ Without affording any effective safeguard against "legislative abdication," the application of the constitutional principle of non-delegation results principally in an additional hazard to the validity of regulatory legislation that confers rule-making powers. ${ }^{48}$ The seriousness of this hazard will be proportional to the necessity for such legislation. If, as legislatures and executives seem to believe and as many are willing to concede, that necessity is great, the success of democratic administration in coping with modern problems is being jeopardized at a vital point. Skillful legislative draftsmanship can minimize the difficulty, ${ }^{49}$ but it is at least arguable that this aspect of the separation of powers ${ }^{50}$ might better have been left in the class of judicially unenforcible constitutional provisions. ${ }^{51}$

It has been claimed, on the other hand, that broad executive rulemaking power, whether conferred by a constitution or by legislative delegation, facilitates the coming of fascism and that a judicial check upon the practice is helpful. ${ }^{62}$ Neither the predominant English view as expressed subsequently by the Committee on Ministers' Powers nor American constitutional doctrine as enunciated by the Supreme Court, however, prevented virtually unlimited delegation in both countries during the World War. ${ }^{53}$ In neither instance did permanent unbalance of the govern-

46. Frequently there is no available procedure for bringing about such review. Moreover, the administrative proceedings, if any, which lead to the promulgation of a general rule usually are not such as result in a record or reveal the precise basis upon which the rule rests. Hence, unless it is clearly ultra vires, the likelihood of its overturn by a court is not great. Black, Is the Test of Recsonableness of an Administrative Determination Subjective or Objective? (1935) 12 N. Y. U. L. Q. REv. 601. The change, if any, which will result from the requirement of the Panama Refining decision [293 U.S. 388 (1934)], that executive regulations be accompanied by "findings," has yet to be ascertained. Compare Pacific States Box \& Basket Co. v. White, 296 U. S. 176 (1935) ; Haines, Judicial Review of Acts of Congress (1936) 45 YALE L. $J$. 816 , at 835 .

47. In England, perturbation over administrative rule-making has centered more largely about the limitation of judicial review of the validity of departmental regulations than about the conference of the initial power to make them. See p. 559, infra.

48. That hazard seems particularly great in many of the states, where judicial objection to regulatory legislation may be less checked by the publicity given to decisions. See, e.g., Ferretti v. Jackson, 188 At1. 474 (N. H., 1936).

49. Ceanmberlain, Legislative Processes (1936) 15-17.

50. The doctrine of the non-delegability of legislative power rests alsu upon the theory that authority cannot, generally speaking, be delegated by the person or body to whom it is entrusted. Duff \& Whiteside, Delegata Potestas non Potest Delegari (1929) 14 CoRs. L. Q. 168.

51. Dodd, Judicially Non-enforceable Constitutional Provisions (1931) 80 U. or PA. L. REV. 54.

52. See Jacoby, Delegation of Powars and Judicial Review (1936) 36 Cou. L. Rev. 871, at 905-907; Cavers, Book Review (1938) 47 Y ALE L. J. 675.

53. Carr, op. cit. supra note 37, at 18; Comment (1933) 33 CoL. L. REv. 1197. The English war-time rule-making power was conferred in the famous Defense of the Realm Act (D.O.R.A.), 4 \& 5 GEo. V, c. 29. 
mental system result. ${ }^{54}$ Moreover, if legislative resistance to authoritarian government is overcome by international pressure or by economic conditions or by the threatened use of force, as it was in the European countries which have yielded to dictatorship, a thin black line of judges, whether superannuated or rejuvenated, is unlikely to afford a sufficient defense. Authoritarian government is a horse of different color from the steed of executive administration performing in the presence of a popularlyelected legislature. Even when the executive is given complete discretionary power in some field of administration, as ordinarily it would not be, that power is subject to withdrawal. Power over the legislature itself is a different matter, which the cases do not touch.

b. Difficulties with Administrative Adjudication. The most widely accepted concept of the mental process of adjudication asserts that the process involves the ascertainment of facts and the application of the law to them. ${ }^{.5}$ It is nowhere denied that administrative authorities engage in this process to a large extent. When they do so in the routine performance of non-discretionary functions, such as the malking of arrests, the abatement of obvious nuisances, the issuance of many types of licenses, and the conduct of public services, no question of violation of the doctrine of the separation of powers arises. It is clear also, as the concept of adjudication would indicate by contrast, that many discretionary decisions are clearly suitable for administrative rendering. ${ }^{\text {to }}$ Some-are regarded as inherently administrative in character. ${ }^{\text {bt }}$ Difficulty arises when determinations are required of administrative authorities in classes of cases traditionally entrusted to the judiciary or similar to such cases in the types of interests involved. The difficulty would be less than it is if the judicial process actually carried on by courts always answered to the concept set forth above and if the courts had not chosen, for certain purposes, to emphasize "judicial discretion" as a distinguishing characteristic of the functioning of judicial bodies. The latter source of trouble may be considered first.

The prerogative writs or extraordinary legal remedies of certiorari and prohibition are supposed to issue only to inferior judicial bodies

54. In England the Emergency Powers Act of 1920 [10 \& 11 GEo. V, c. 55] remains in force, with an amendment not here relevant, but the power which it confers is strictly hedged about with safeguards. $17 \& 18 \mathrm{GEo}$. V, c. 22, §1(4).

55. Brandeis, J., dissenting, in International News Service v. Associated Press, 248 U. S. 215 , at 262 (1918). See also Dickinson, op. cit. supra note 7, at 15-25. The concept of adjudication, or the mental process by which issues are decided, is different from that of a court, the type of agency which traditionally has carried on the process. The latter embraces the manner in which a question arises for decision (case or controversy) and the force which is given to the judgment when rendered. Aluskrat v. United States, 219 U. S. 346 (1911).

56. See p. 544, supra.

57. See p. 553 ff., infra. 
for the purposes, respectively, of correcting errors of law in cases in which no appeal lies and of preventing further proceedings in certain cases in which the lower tribunals lack jurisdiction. It has long been established that not only the proceedings of actual courts, but also those of tribunals whose proceedings are "judicial in nature," can be reached by means of these writs. ${ }^{58}$ In determining what proceedings fall within this category the courts have had occasion to discuss the nature of the judicial process. They have chosen at times to emphasize "discretion" as the element which distinguishes it from the process which accompanies "merely ministerial" administrative acts. ${ }^{58}$ It is difficult to see exactly what has been meant by this, but apparently the exercise of deliberation, the careful weighing of evidence, and the application of rules of law, more or less vague, have been elements in "judicial discretion" for this purpose. ${ }^{60}$ Not only has this theory of the judicial process resulted in confusion in the field in which it has been employed, ${ }^{61}$ but it also runs directly counter to the basic concept of the administrative process in numerous fields, ${ }^{62}$ and verbally counter to the most frequent concept of the judicial process.

It is true, moreover - turning now to the first of the two difficulties mentioned above - that, realistically viewed, the judicial process contains more discretionary elements than orthodox theory has for most purposes been wont to assume. ${ }^{63}$ When, therefore, the legislature attempts to transfer to administrative agencies certain classes of cases which traditionally have fallen to the judicial branch, it is not unnatural for the courts in applying the doctrine of the separation of powers to stress the importance of their discretionary functions and to inquire whether any of them have been transferred. If so, they are likely to brand the delegation as invalid despite the fact that, looked at as a whole, the work of the executive is more largely characterized by discretion than that of the judiciary. Thus the constitutionality of workmen's compensation acts has been established partly by reason of the elimination of negligence as

58. Dickinson, op. cit. supra note 7, at 43.

59. Finkelman, Separation of Powers: A Study in Administrative Law (1936)

1 U. of Toronto L. J. 313, at 324-326.

60. Dickinson, op. cit. supra note 7 , at 150 .

61. Finkelman, supra note 59, passim.

62. See p. 546, supra.

63. It is, of course, this aspect of judicial functioning which has led the legal "realists" to minimize the role of legal rules in the determination of cases by the courts. Not only does judicial behavior, especially in the trial courts, often proceed in disregard of the rules, but the rules themselves often allow ample scope for discretion. This is true (a) where the determination of rather vaguely defined "facts," such as that of negligence, is left to the judge or to the jury, (b) where judges are required to apply flexible concepts, such as fraud, reasonableness, or due diligence, in determining the outcome of cases, and (c) where there is a choice between conflicting rules of law in reaching a decision. 
an issue in the cases and by the reduction of the measure of recovery to fairly definite mathematical calculations. ${ }^{\text {of }}$ When, with less cate or less possibility of altering the substantive law, the legislature attempts a simple transfer of functions from the courts to administrative agencies, adverse decisions are likely to result. ${ }^{\text {or }}$ Although some of these decisions may be accounted for on other grounds, ${ }^{C B}$ although others are quite liberal, ${ }^{6 \tau}$ and although it may be argued that demonstrated necessity will overcome constitutional objections in future instances as in the workmen's compensation cases, there still remains a very real hazard to the extension of administrative control over troublesome areas of modern life $e^{88}$ in which judicial action is pretty clearly inadequate. ${ }^{60}$ While the problem has not become of major importance in the connection now under discussion, future decisions ought rather to be grounded upon the necessity both of providing procedures adapted to the determination of the various types of controversies, and of allocating functions accordingly. This reform would not merely minister to the comfort of academic theorists who are interested in logical consistency ${ }^{70}$ but would also result in decisions that would be more likely to promote efficiency and fairness in the administrative and judicial systems. ${ }^{71}$

c. Judicial Participation in Admintistration. If it is one corollary of the separation of powers that essential judicial functions may not be withdrawn from the courts, it is another that non-judicial functions may not be imposed upon them. This corollary has two chief consequences in the field of administration: first, that the courts cannot be required to render advisory opinions to administrative agencies and second, that judicial review of administrative decisions must be limited to elements regarded as judicial.

64. Borgnis v. Falk Co., 147 Wis. 327, 133 N. W. 209 (1911); Grand Trunk: Western R.R. v. Industrial Commission, 291 III. 167, 125 N. E. 748 (1920).

65. Pillsbury, Administrative Tribunals (1923) 36 HAnv. L. Rev. 405; Brown, Administrative Commissions and the Judicial Poucr (1935) 19 A[nu. L. REv. 261; In re Opinion of the Justices, 87 N. H. 492,179 Atl. 344 (1935); Klcin v. Barry;, 182 Wis. 255, 196 N. W. 457 (1923).

66. E.g., the binding of persons not parties to the administrative proceedings by the resulting decisions under attempted Torrens Acts. State v. Guilbert, 56 Ohio St. 575, 47 N. E. 551 (1897).

67. Farm Investment Co. v. Carpenter, 9 Wyo. 110, 61 Pac. 258 (1900). See Wiel, Administrative Finality (1925) 38 HARv. L. REv. 447.

68. In re Opinion of the Justices, 87 N. H. 492, 179 Atl. 344 (1935).

69. Marx, Compulsory Compensation Insurance (1925) 25 Col. L. REv. 164; Symposinm on Autonobile Traffic Accident Compensation (1932) 32 CoL L. REv. 785; Comments (1930) 16 A. B. A. J. 97, 753; Deak, Lialility and Comprnsation for Automobile Accidents (1937) 21 Mins. L. Rev. 123.

70. Compare Gavit, Legal Conclusions (1932) 16 Afus:. L. REv. 378; (1933) 9 IND. L. J. 109.

71. See p. 566, infra. Landis, Administratice Policies and the Courts (1938) 47 Yale L. J. 519, 535 et seq. 
The proposal was made in England in 1928 to require the judges to give opinions upon questions of law arising under the Rating and Valuation Bill of that year. ${ }^{72}$ This suggestion met with the virtually unanimous condemnation of the legal profession on the ground that the judiciary should not be dragged into the consideration of administrative measures at times when policy is being formulated, and it was quickly dropped. ${ }^{73}$ Legal views of the separation of powers conflicted in this instance with the political notion that administration should be enabled to proceed with assurance to the accomplishment of its appointed ends.

More recent English legislation for effecting housing reform and other public improvements has tended to the provision of statutory appeals from orders for improvement schemes within a limited period following their approval by the Minister of Health. ${ }^{74}$ Thus, affected property owners are afforded a simplified, less expensive procedure for raising legal objections than was available before, and the execution of the schemes is enabled to proceed with greater certainty after the expiration of the statutory period. It has been suggested that it would be desirable "to set up some permanent body clothed with power to review all delegated legislation as it issued and quash any that went beyond the statutory power." 75 In this country it has recently been proposed to employ the Court of Claims as such a body without, however, superseding existing methods of judicial review of administrative regulations. ${ }^{76}$ Under this plan proceedings might be instituted "in accordance with the rules of the said court." 77 Since the Court of Claims has been catalogued as a "legislative court" and not a court in the constitutional sense, ${ }^{78}$ no question of the imposition of non-judicial functions upon a

72. See Allen, Bureaucracy Truumphant (1931) at 59, $106 \mathrm{ff}$.

73. Ibid.; WILlIs, op. cit. supro note 14, at 181-2. For the earlier English history see Frankfurter, Advisory Opinions (1930) 1 Encyc. Soc. Scrences 475.

74. Willis, op. cit. supra note 14 , at 140.

75. Id., at 181. See also Arnold, Trial by Combat and the New Deal (1934) 47 Hanv. L. REv. 913. For the sake of greater thoroughness and certainty in judicial review of administrative acts, including general regulations, Professor Arnold is willing to increase the power of the courts many fold.

76. Report, Amer. Bar Association Special Committee on Aduinistrative Law (1937) at 170,197, 225.

77. Id., at 225.

78. Williams v. United States, 289 U. S. 553 (1933). Until the decision in Ex parte Bakelite Corp., 279 U. S. 438 (1929) the Supreme Court looked upon the Court of Claims as a judicial body. For that reason the review which the high court gives to the decisions of the latter [28 U. S. C. $\$ 288$ (1934)] has been regarded as appellate in character and not as an exercise of original jurisdiction on the part of the Supreme Court. The latter could not be forced upon it. Marbury v. Madison, 1 Cranch 137 (U.S. 1803). It is difficult to see how the historical deposit of decisions in regard to the Court of Claims can be fitted into a logical pattern. For analyses of the holdings in this field see Katz, Federal Legislative Courts (1930) 43 HaRv. L. REv. 894; Comment (1934) 34 CoL. L. REv. 344, 746. 
judicial body is precipitated by the proposal. It is not clear whether proceedings by a mere citizen, which would eventuate in advisory opinions after-the-fact, or declaratory judgments are contemplated. ${ }^{70}$ The practical question of the desirable scope of judicial review of administrative determinations is raised, however, by the fact that the Court of Claims functions in the manner of a judicial body. ${ }^{80}$ As to other courts, this issue ties itself to the constitutional question of the permissible scope of judicial review.

It is recognized that administrative proceedings may give rise to issues which are constitutionally suitable for judicial determination. These may be collateral issues, such as the liability of a witness to testify, ${ }^{82}$ questions of law involved in the main issue to be determined, ${ }^{82}$ or the entire case if it is of a nature which causes it to be looked upon as justiciable, although it does not forbid administrative handling. ${ }^{83}$ It is the second class of issues that requires definition in the effort to impose no more functions upon the judiciary than the courts regard as falling vithin their province. In several cases the Supreme Court refused to entertain appeals from decisions of the District of Columbia Court of Appeals in which that body had reviewed administrative decisions upon the ground that the lower court had been required by the statute to. make administrative as well as judicial determinations. Hence the Supreme Court's power of review was regarded as one of original judicial jurisdiction and therefore as unconstitutional. ${ }^{84}$ In these decisions the Supreme Court reasoned from the premise that the administrative proceedings involved, being discretionary or policy-determining in character, ${ }^{85}$ were essentially "legislative." 88 This characterization applies particularly to the

79. Compare "any person adversely affected may petition" [see sipro note 76 , at 170] with "the citizen or other person affected" [Id., at 197]. See also, Borchard, Declaratory Judgments in Administrative Law (1933) 11 N. Y. U. L. Q. REv. 139; Ellingwood, Declaratory Judgments in Public Law (1934) 29 ILL. L. REv. 1, 17-23, 175-180, 204-213.

80. See Frankfurter and Landis, The Busmess of the Suprese Court (1928) at 63 .

81. Interstate Commerce Comm. v. Brimson, 154 U. S. 447 (1894).

82. Federal Radio Comm. v. Nelson Bros. Bond \& Mortgage Co., 289 U. S. 266 (1933).

83. Tutun v. United States, 270 U. S. 568 (1926) (naturalization); Cleveland Trust Co. v. Nelson, 51 F. (2d) 276 (E. D. Mich., 1931) (right to patent).

84. Keller v. Potomac Electric Power Co., 261 U. S. 428 (1923); Federal Radio Comm. v. General Electric Co., 281 U. S. 464 (1930). Compare the authorities cited in note 78, supra. The conference of non-judicial functions upon the Court of Appeals presents no constitutional difficulties since it, like the Court of Claims, is a "legislative court"-although not for all purposes. O'Donoghue v. United States, 289 U. S. 516 (1933).

85. See p. 544 ff., supra.

86. Prentis v. Atlantic Coast Line Ry. Co., 211 U. S. 210 (1908). 
licensing and rate-fixing functions of administrative agencies. The present Communications $\mathrm{Act}^{87}$ retains the formula for judicial review in licensing which the Court approved in the Nelson Brothers Bond \& Mortgage Co. case. ${ }^{88} \mathrm{By}$ it the courts are limited to affirming or reversing and remanding the administrative decisions coming before them, and their review is restricted to questions of law unless it clearly appears that the administrative agency's findings of fact are "arbitrary or capricious." In the fields to which it is applicable, it affords a reasonably satisfactory solution to a difficult problem. ${ }^{89}$ It is, of course, not binding upon the states, which are free to distribute the powers of government as they choose. ${ }^{80}$

The conception of judicial review involved in the Supreme Court cases has in one situation been used in a negative way to deny the character of judicial to "legislative" review by a state court. Consequently, although the review was actually afforded by the same court that exercised judicial powers and although it embraced all that "judicial" review could include and more besides, it was declared necessary to superadd a strictly judicial review under the state law in order to forestall the intervention of a Federal court under the terms of the Johnson Act. ${ }^{91}$ The purpose of this Act is to secure an adequate opportunity for judicial review to utilities in rate proceedings and to prevent the entertainment of injunction proceedings by the Federal courts where such review is available. ${ }^{92}$ The result of the decision is conceptualism run riot, ${ }^{83}$ with the effect of compelling the states to limit court review under their own laws as the price of forestalling the intervention of the Federal courts. It is difficult to see what interest will be furthered in

87. Communications Act of $1934, \S 402(\mathrm{e})$. 48 STAT. 1093,47 U. S. C. A. $\$ 402(\mathrm{e})$ (Supp. 1937).

88. Federal Radio Comm. v. Nelson Bros. Bond \& Mortgage Co., 289 U. S. 266, at 275 (1933).

89. It is not applicable, of course, to all fields of administration, for quite different formulas for the scope of judicial review are more suitable in many fields. Dickinson, Judicial Control of Official Discretion (1928) 22 Ans. Por. Scr. Rev. 275; Isaacs, Judicial Review of Administrative Findings (1921) 30 YALE L. J. 781; Albertsworth, Judicial Reviezw of Administrative Action (1920) 35 HARv. L. REv. 127; Tollefson, Administrative Finality (1931) 29 Mrcrr. L. Rev. 839; Dickinsos, op. cit. supra note 7 , at 56-62. When variations are in the direction of restricting the scope of judicial review, they do not raise the issue of the imposition of non-judicial duttes upon the courts.

90. See Prentis v. Atlantic Coast Line Ry. Co., 211 U. S. 210 (1908); Porter v. Investors' Syndicate; 286 U. S. 461 (1932).

91. Corporation Commission of Oklahoma v. Cary, 296 U. S. 452 (1935).

92. Comment (1934) 44 YaLE L. J. 119. The Act provides that an injunction shall not issue if a "plain, speedy, and efficient remedy may be had at law or in equity" in the state courts. 48 StaT. 775 (1934), 28 U. S. C. $\$ 41$ (1) (Supp. 1937).

93. Merrill, Does "Legislatiz'c Review" by Courts in Appeals from Public Utility Commissions Constitute Due Process of Law? (1926) 1 IND. L. J. 247. 
the long run by such a holding; but in the meanwhile the purpose of Congress is to some extent nullified.

The error of providing too much judicial review, it must be noted, is not far removed from the failure to provide enough; for the requirement of due process of law must be observed in American legislation at the same time that heed is paid to the theory of the separation of powers. It is over the desirable minimum of legislative provision of judicial review and of judicial assertion of reviewing powers that much of the clash of theories in administrative law has taken place. This subject, in turn, relates to that of the optimum distribution of controlling powers in administration. The discussion may now proceed to a consideration of these questions.

\section{The Preservation of the "Rule of Law" Through Judicial Control of Administration}

a. The Classic Theory. It is impossible within the space of a single article to discuss even in outline the entire subject of judicial review of administrative determinations. In the course of the extensive consideration given to this topic ${ }^{94}$ much has been said of the "rule of law" on the one hand and of the desirability of securing administrative responsibility to higher political authority, in order that current policies may be well effectuated, on the other. These opposing views, emanating from legal and political sources respectively, challenge not only each other but also the view that what need primarily to be considered are the practical ends that lie back of the concepts.

Dicey, whose name is most frequently and most prominently associated with the "rule of law" and who gave it its classic formulation, divided it into three aspects: (1) "that no man is punishable or can be lawfully made to suffer in body or goods except for a distinct breach of law established in the ordinary legal manner before the ordinary courts of the land;" (2) "that . . . every man, whatever be his rank or tradition, is subject to the ordinary law of the realm and amenable to the jurisdiction of the ordinary tribunals;" ${ }^{30}$ and (3) "that the general principles of the constitution . . . are with us the result of judicial decisions determining the rights of private persons in particular

94. See authorities cited supra nate 89, and Landis, Administraliz' Folicies and the Courts (1938) 47 Yale L. J. 519; Freusd, Adursistantite Powens olen Pensosis aNd Property (1928) cc. 13, 14, and 15; Comment (1935) 35 CoL. L. Rev. 230; Powell, Principles of Judicial Reziew (1913) 28 PoL. Scr. Q. 34; Comment (1934) 43 Yale L. J. 599; Comment (1933) 33 CoL L. Res. 105; MrcFanla:id, Judictar Review of the Interstate Comarerce Cosisussion axd the Fenemal Trade Cousaissiox (1933); Brown, Functions of Courts and Commissions in Public Utility Rate Regulation (1924) 38 HARv. L. Rev. 141.

95. LAW of the Cosstitutios (1885) 172.

96. Id., at 177 . 
cases brought before the Courts." ${ }^{97}$ The first aspect, according to Dicey, stands in contrast to "the exercise by persons in authority of wide, arbitrary, or discretionary powers of constraint;" the second to a system of droit administratif, in which public officials are not answerable for their official acts in the ordinary courts but, instead, to administrative tribunals; and the third to systems in which "the security (such as it is) given to the rights of individuals results, or appears to result, from the general principles of the constitution." In so far as the "rule of law" is looked upon as good-as of course it is-all three aspects magnify the beneficence and importance of the courts.

Although the preceding discussion has shown that the distrust of discretionary administrative powers on the part of Dicey and his followers has not prevented the increase of these powers, it has also shown that the desire to limit them as much as possible is widespread. Dicey himself later modified his unfavorable judgment of French droit administratif, ${ }^{98}$ and the notion that during the past half century it has represented tyranny in any sense has been completely exploded. ${ }^{90}$ The Committee on Ministers' Powers, however, still felt called upon in 1932 to reject emphatically the suggestion that a similar system of administrative tribunals be set up in England, upon the ground of "the fundamental necessity of not only maintaining but strengthening the supremacy of the Law," which "involves the equal subjection of all classes to regular Law administered by the ordinary Courts of Law." 100 The notion that the courts are the sole authors of liberty under the English constitution is obviously contrary to the facts ;101 but it is still possible for the editors of an important current work to utter the solemn absurdity that "In comparison with cases, statutes have for the most part only a fleeting interest. They indeed regulate the constitution and powers of most of our public authorities, but the mode of exercise of those powers is in the main a matter of Common Law." 102

With such an attitude prevailing in important quarters, it is small cause for wonder that attempts to limit or abolish judicial review of administrative determinations should result in protests and in effort on the part of the courts to escape from the limitations. Nor is it surprising that courts should display a tendency to exercise broadly those powers

97. Id., at 208 .

98. LAW OF THE Constitution (8th ed. 1915) Introduction; Frankfurter, The Task of Administrative Law (1927) 75 U. of PA. L. REv. 614, at 615.

99. Garner, French Administrative Law (1934) 33 YALE L. J. 597; Garner, AngloAmerican and Continental European Administrative Law (1930) 7 N. Y. U. L. Q. REv. 387; Morgan, Introduction to Robinson, Public Authorities aNd Legal Liadility (1925) at 1 xii-lxvii.

100. REPORT (1932) 113.

101. Jennings, The Law and the Constitution (1933) 34-36.

102. See Keir \& Lawson, Cases in Constitutional Law (1928) at vi. 
of review which they have always had or which legislation has conferred upon them and which there has been no effort to limit. For both these tendencies there is, moreover, a reason more fundamental than affection for the courts as institutions; for it has been perceived that the legislation conferring administrative powers is collectivist, or "socialistic," in its purposes. Dicey, who gave clear expression to his understanding of this tendency in modern legislation, ${ }^{103}$ was able on the whole to view it with detachment and to expound it intelligently. As much cannot be said for some others who believe they sense the same truth. Thus it has been said that the "creed of socialism" embodied in the Housing Acts involves "the obliteration of private rights," apparently without discrimination. ${ }^{104}$ It follows that the "interference with private rights," resulting from legislative effectuation of "socialism," "must be limited to such a degree as is in accordance with public opinion;"105 this Parliament, no doubt, does not reflect, and, therefore, it must be effectuated by the courts. It is still, in this view, no part of the business of government to provide the necessaries of life to the people. ${ }^{103}$ Since the contrary creed, which actuates the legislation, is not expressed upon the face of the statutes, the judges can and do, while adhering to alleged canons of statutory construction, exercise their reviewing function in the light of their own views of policy so as at times to limit the effectiveness of the administrative powers conferred. ${ }^{107}$ Hence legislation and administration, representing the force of collectivism, claşh to some extent with the courts, representing the interests of property owners; and the "rule of law" takes on a deeper significance.

b. Review of Administrative Rule-Making. Attempts on the part of Parliament to eliminate judicial review of the regulations resulting from certain delegated rule-making powers furnished the principal ground of attack in 1929 upon the "New Despotism" of administrative authorities. Lord Chief Justice Hewart, in that year, published his colorfully-entitled volume ${ }^{108}$ and precipitated the agitation that led to the appointment of the Committee on Ministers' Powers. Lord Hewart depicted a permanent bureaucracy grasping for power and rapidly securing it by means of the delegation to itself of broad rule-making authority in legislation which it drafted and foisted upon an unsuspecting Parliament and public. In order to overcome the last defense of the citizen, the legislation fore-

103. Law and Opinion in England (1905) passim.

104. Potter, Legislative Powers of Public Authorities (1928) 6 J. Pud. Ad:str. 32, at 39 .

105. Ibid.

106. See Mfarrtott, How England Is Governed (1928), at 86.

107. Jennings, Courts and Administrative Law-The Experience of English Housing Legislation (1936) 49 HARv. L. REv. 426.

108. Hewart, Taz New Desforisar (1929). 
stalled judicial-review by giving to the departmental regulations the final effect of statutory provisions. An undercurrent of similar criticism that had been running for some time, was fed by additional streamlets thereafter. ${ }^{109}$

The Committee on Ministers' Powers was unable to uncover the fire of which the Lord Chief Justice thought he had seen the smoke. While asserting that the public should be "grateful for outspoken criticism, even if exaggerated," 110 the Committee negatived "the suggestion, unsupported as it is by the smallest shred of evidence," that the curtailment of judicial review in certain statutes "is due directly or indirectly to any attempt or desire on the part of members of the permanent civil service to secure for themselves or for their Departments an arbitrary power." 111 On the contrary, the Committee saw "nothing to justify any lowering of the country's high opinion of its civil service or any reflection on its sense of justice, or any ground for a belief that our constitutional machinery is developing in directions which are fundamentally wrong." 112

The attempted immunization of departmental regulations from judicial review is the product of a system of legislation and of administrative powers which should be outlined briefly. Important bills are introduced and sponsored in Parliament by the government. The departments concerned play a large part in their preparation. On the legal aspects of proposed measures the solicitors of the departments are consulted. The actual work of drafting centers in the office of the Chief Parliamentary Counsel, nominally in the Treasury Department. Many of the most important measures resulting from this process have conferred extensive rule-making powers upon the departments. Usually the authorized regulations are framed and announced by the departments themselves; but under certain laws concerning local improvements and measures of economic reconstruction within particular industries, "schemes" formulated by local authorities or by statutory boards or corporations are submitted for ministerial approval by a procedure which takes the place of the well-known machinery of private bill legislation. Some of the resulting rules and "schemes" require enactment as laws by Parliament before taking effect; some call for approval by resolution; most take effect after having lain before Parliament a specified number of days without adverse action by that body; and a smaller number are made effective through departmental action alone. Those of general application are published in the annual volumes of Statutory Rules and Orders, whose bulk in com-

109. Allen, Bureaucracy Triumpeant (1931); works cited in Wrlurs, op. cit. supra note 14, at 29, and Finkelman, loc. cit. supra note 59; KEIR \& LAwsoN, op. cit. supra note 102, at 143.

110. REPORT (1932), at 7.

111. Id., at 59.

112. Id., at 7. 
parison with that of the acts of Parliament has been a matter of much comment. Power to adopt regulations which shall take effect as if enacted in the authorizing act and the power to modify an act by rule have been conferred upon government departments. Both of these types of rulemaking authority are immune from judicial check to an undetermined extent. Occasionally even more drastic power has been bestowed. ${ }^{113}$

In the absence of alertness and independence on the part of Parliament, ${ }^{114}$ there seems on the face of the foregoing system to be an almost perfect opportunity for the seizure of power on the part of the administration. Actually, as the conclusions of the Committee on Ministers' Powers indicate, nothing of the sort has occurred. Not only is there no discoverable disposition on the part of the civil service to engage in any such usurpation, but important decisions in the preparation of bills are made, it is alleged, by the responsible ministers themselves. ${ }^{115}$ The departmental solicitors are lawyers jealous of their professional independence and integrity. ${ }^{116}$ The office of Parliamentary Counsel is careful to remain within the limits of approved policy. Where broad rule-making powers are in terms conferred, they have, almost without exception, been used for limited and proper purposes. ${ }^{117}$ At most, the system has lacked uniformity and simplicity, and there has been some tendency to employ unnecessarily such stock phrases as the one that regulations "shall have effect as if enacted in this Act."118 Thus the check of judicial review,

113. Detailed citation of supporting authorities will not be attempted here. All of the points mentioned are covered in detail in worlss already cited and in ILDERT, MErmons of Legtslation (1912) and The Mechanics of Lay Mannic (1914); Famrie, Adainistrative Procedure in Connection with Staturory Rules and Ondezs in GrEAT BrITAIN (1925). As regards economic reconstruction by industries in the field of agriculture see Elliot, Solutions of Certain New Problems in Administration (1936) 14 J. Pub. Adurn. 1. For similar legislation in related fields see Jennings, Noles on Administrative Law (1937) $15 \mathrm{~J}$. PuB. Adusu. 97.

114. The thesis that in most matters Parliament is thoroughly controlled by the government in power is stated in MIUIs, How Britain Is Goverwed (1929).

115. Comamtiee on Ministers' Powers, Minutes of Evidence (1932) at 3 (testimony of Sir Maurice L. Gwyer, Treasury Solicitor).

116. Id., at $2,7$.

117. Conmittee on Ministers' Powers, Memoranda dy Govermesent DepatsMIENTS (1932) 31-33; REPoRt at 54; Wrulis, op. cit. supra note 14, at 151. "In my' experience few powers are exercised by the Department with more anxious care, and I would add, with a greater desire to serve the public, than the power to malse rules and regulations which have the force of law." Gwyer, The Pourers of Public Defartments to Make Rules' Having the Force of Law (1927) 5 J. Pub. Anurs. 404. It has, however, been asserted that income tax regulations have occasionally been framed with deliberate vagueness so as to keep would-be tax avoiders guessing and permit interpretation that might defeat their schemes. WuLIs, op. cit. supro note 14 , at 54 .

118. Commimtee on Ministers' Powers, Minutes of Endoerce (1932) at 4 (testimony of Sir Maurice L. Gwyer). 
if needed at all, is needed for less weighty reasons than the defeat of tyranny.

Potential rather than actual danger ${ }^{119}$ has been suggested as a justification for the recommendation that judicial review of the vires of administrative rules should in virtually all cases be preserved. ${ }^{120}$ Whatever the reason, the practice of providing explicitly for such review and for review of departmental compliance with due procedure in the framing of regulations has become quite uniform in recent English "scheme" legislation. ${ }^{121}$ The crucial issue is whether the resulting elimination of "potential" danger of administrative abuse is purchased at the price of actual unwarranted judicial interference with administration. One observer states that in the case of housing legislation it has. ${ }^{122}$ Although statutory appeals are limited in point of time, principles of strict construction, extending to the details of administrative procedure, have been followed in the decisions. In order to overcome them and forestall future decisions of the same kind, the statutes are being made "more and more detailed" and are certain to "give rise to increasing difficulties of interpretation." The English courts have also exhibited a tendency to extend their nonstatutory powers of review. In 1929 a housing scheme was held sufficiently "judicial" to justify the use of the writ of prohibition to prevent its further consideration because the scheme's sweeping terms were thought to make it ultra vires. ${ }^{123}$ Certiorari has become a recognized means of reviewing the procedural aspects of the formulation of such schemes following their departmental approval. ${ }^{124}$ Although statutory appeals are now substituted for these non-statutory proceedings in the field of housing and slum clearance, the cases remain as precedents for the review of other administrative determinations.

All in all, therefore, one may say with regard to judicial review of the exercise of delegated rule-making power in England, that its alleged justification in actual administrative abuse has been disproven, that its scope has to some extent been enlarged by Parliament as a safeguard against "potential" abuse, and that the consequences may be harmful unless judicial appreciation of the work of the "bureaucracy" increases as a result of its vindication by the Committee on Ministers' Powers and as a consequence of the growing necessity for it. In the United

119. Committee on Ministers' Powers, Report (1932) at 54.

120. Id., at 61 .

121. Fart, Administration and the Law (1936) 14 J. Pub. Admin. 301; Wilnis, op. cit. supra note 14, at 41 .

122. Jennings, Courts and Administrative Law-The Experience of English Housing Legislation (1936) 49 HARv. L. Rev. 426; Hart, loc. cit. supra note 121.

123. Rex v. Minister of Health [1929] 1 K. B. 619. See also Rex v. Electricity Commissioners [1924] 1 K. B. 171.

124. Minister of Health v. The King on the Prosecution of Yaffe [1931] A. C. 494 , at 513 . 
States no similar problem of judicial review has as yet arisen with regard to administrative rule-making. ${ }^{200}$

c. Review of Administrative Decisions. That aspect of the "rule of law" which relates to judicial review of administrative decisions, i.e., orders directed to particular situations or persons, stands upon a somewhat different footing from review of general regulations. Not only are persons and property immediately affected by such orders; not only are the courts more at home in this field; but, in addition, some evidence of definite abuses by administrative authority has been brought forward. In England unauthorized exaction of money in connection with the issuance of licenses seems to have occurred (although not for the personal profit of officials) ${ }^{126}$ the Federal Trade Commission was for some years guilty of unfairness in its proceedings; ${ }^{127}$ the conduct of deportation proceedings in the United States was at one time a national scandal; $;^{128}$ and the occasional malpractices of incompetent, politicallychosen local officials in the administration of occupational licensing, health, and building laws are a matter of common knowledge. If judicial review can aid in correcting such conditions without unduly hampering administration, it will assist materially in the governmental process.

Unfortunately, however, judicial review has only occasionally reached the evils which call for correction. The fault in this connection does not lie with the judges. Either the available procedure for invoking their review has been expensive or unknown to the uninformed persons with whom the administration has dealt, as in the field of deportation, or else it has been impossible for the courts, exercising a review limited to questions of law and to procedural errors appearing on the face of a written record, to penetrate to the factual issues that usually lie at the center of the difficulty. ${ }^{129}$ Review by non-expert judges or juries of the technical fact determinations involved in large areas of modern administration, even where private interests are directly affected, would be neither desirable nor possible. ${ }^{130}$ The courts themselves have generally recognized their relative incompetence in such matters. At the same

125. See note 46 , supra.

126. AlLEN, op. cit. supra note 109, at 36-39.

127. Henderson, The Federal Trade Cosizission (1924) cc 2, 3.

128. Report, National Consurssion on Law Obsenvamce amd Law Emfonceneis (1931) Part 5; VanVleck, The Adrinistratrve Contmol of Alietis (1932); Clarts, Deportation of Alrens from tee United States to Eubope (1931).

129. The Special Committee on Administrative Lav of the Ameriean Bar Association has rightly emphasized the critical importance of the facts in administrative proceedings as in judicial. 61 A. B. A. REP. 720, at 739-740, 764-765 (1936); 59 A. B. A. REP. 539, at 546-547 (1934). See also Guthrie, Problems of the Bar (1923) 46 N. Y. STATE B. A, REP. 169.

130. Dickinson, op. cit. supra note 7, at 71-73, 254; Hendenson, op. cit. siffo note 127 , at 97 . 
time they often have felt impelled to assert to the limit such powers as they have possessed, both for the purpose of preserving a vaguely-defined "rule of law" and of indirectly checking what they have regarded, rightly or wrongly, as administrative abuses.

Judicial review has done its part in reversing arbitrary action and in establishing norms of administrative procedure. ${ }^{131}$ Its operation, however, has not always been attended with happy resuilts. The issues in cases involving the review of administrative decisions have too often related, on the one hand, to collateral points of administrative procedure ${ }^{132}$ and, on the other, to matters of judgment, such as the value of a utility's property, which the courts have been able to brand as questions of law ${ }^{138}$ or of "constitutional" or "jurisdictional" fact ${ }^{134}$ — upon many of which they are at least as likely as an administrative commission to be wrong. Public interest as seen by an administrative agency and private interest as represented by a particular respondent have contended for advantage in the judicial forum and have necessarily centered upon fragmentary issues.

An enlarged conception of the proper role of the courts in their review of administrative determinations is indicated by a series of recent decisions of the Supreme Court. Although it had long been established as a general proposition that "due process is not necessarily judicial process," 135 it has now been decided that, after all, due process of law requires judicial determination of the facts involved in issues of constitutional right in administrative proceedings. Thus the minimum valuation of a public utility which will avoid "confiscatory" consequences in a ratefixing proceeding must be left open to determination by a judicial body exercising its "independent judgment" whenever the issue is raised. ${ }^{100}$ The fact of alienage is, as a matter of due process involving the deter-

131. Ohio Bell Telephone Co. v. Public Utilities Commission of Ohio, 301 U. S. 292 (1937) ; Motr, Due Process of LAw (1926) 216 ff.; Comments (1931) 80 U. of PA. L. Rev. 96, 878; (1934) 34 CoL. L. Rev. 332; Hanft, Utilities Commtissions as Expert Courts (1936) 15 N. C.. L. REv. 12.

132. Federal Trade Commission v. Gratz, 25.j U. S. 421 (1920); Kwock Jan Fat v. White, 253 U. S. 454 (1920) ; Lloyd Sabando Societa v. Elting, 287 U. S. 329 (1932); United States v. Abilene \& Southern R. Co., 265 U. S. 274 (1924); United States v. B. \& O. R. Co., 293 U. S. 454 (1935).

133. Federal Trade Commission v. Gratz, 253 U. S. 421 (1920) (nature of unfair competition); International Shoe Co. v. Federal Trade Commission, 280 U. S. 291 (1930) (sufficiency of evidence to support finding of substantial lessening of competition by merger) ; Smyth v. Ames, 169 U. S. 466 (1898) (method of valuing railway property for rate-fixing purposes).

134. Crowell v. Benson, 285 U. S. 22 (1932) (existence of employer-employee relationship in compensation proceeding).

135. MOTT, op. cit. supra note 131 , at 215.

136. Ohio Valley Water Co. v. Ben Avon Borough, 253 U. S. 287 (1920); Tagg Bros. \& Moorhead v. United States, 280 U. S. 420 (1930). 
mination of a "jurisdictional fact," open to judicial reexamination upon review of a deportation proceeding. ${ }^{137}$ "Jurisdictional" facts in Federal administrative proceedings which the Supreme Court calls judicial must be determined by a court because it is essential to the preservation of the judicial power under the Constitution that they be not settled conclusively by administrative determinations. Hence the existence of the employer-employee relationship between the claimant and the respondent in a Federal workmen's compensation proceeding, which is said to be essential to the power of Congress to provide for liability without fault, is "jurisdictional," and a reviewing court must be free to determine it for itself. ${ }^{138}$ Finally, the court is free in a rate case, if it thinks proper, to admit additional evidence upon the issue of confiscation even where, upon statutory review of a Federal agency's decision, it is confronted with an administrative record. ${ }^{130}$

Thus, by means of doctrines created out of whole cloth, the Court has raised the strong possibility that administrative proceedings of the highest importance will be rendered less effective by retrials and by judicial reversals upon points which are only fragments of the entire causes. ${ }^{240}$ This development has resulted from a number of factors: in the utility cases, perhaps, a desire to protect the interests of corporate property holders; in the deportation cases a strong disposition to right the wrongs committed by a poorly-manned administrative agency employing an inadequate procedure; and in Crowell v. Benson and St. Joseph Stock Yard Co. $v$. Wallace quite clearly a distrust of administrative agencies and a belief in the superiority of the courts, which is closely analogous to English professional fondness for the "rule of law." It is the latter factor which is of primary concern here. Mr. Chief Justice Hughes, speaking for the Court, gave utterance to his views upon the point:

"The recognition of the utility and convenience of administrative agencies for the investigation and finding of facts within their proper province, and the support of their authorized action, does not require the conclusion that there is no limitation of their use, and that the

137. Ng Fung Ho v. White, 259 U. S. 276 (1922). Because review was had in a habeas corpus proceeding, the court was of course free, if not compelled, to receive evidence upon the issue, if it was to review the point at all.

138. Crowell v. Benson, 285 U. S. 22 (1932). It was held, partly for statutory and partly for constitutional reasons, that the review should be by trial de nozo.

139. St. Joseph Stock Yard Co. v. Wallace, 298 U. S. 38 (1936) ; Baltimore \& Ohio R.R. v. United States, 298 U. S. 349 (1936). The power to admit additional evidence is, however, to be used sparingly. Compare Acker v. United States, 298 U. S. 426 (1936).

140. See the dissents of Mr. Justice Brandeis in Crowell v. Benson, 285 U. S. 22 (1932) and St. Joseph Stock Yard v. Wallace, 298 U. S. 38 (1936) ; Diclsinson, Crourell v. Benson: Judicial Review of Administrative Determination of Questions of "Constitutional Fact" (1932) 80 U. of PA. L. REv. 1055. 
Congress could completely oust the courts of all determinations of fact by vesting the authority to make them with finality in its own instrumentalities or in the Executive Department. That would be to sap the judicial power as it exists under the Federal Constitution, and to establish a government of a bureaucratic character alien to our system, wherever fundamental rights depend, as not infrequently they, do depend, upon the facts, and finality as to facts becomes in effect finality in law." 1 s1

Whether the courts actually furnish superior security to liberty and property; whether administrative findings upon "facts" such as valuation, which are matters of judgment, are more likely to be "wrong" than the conclusions of the courts; and whether the courts or administrative agencies are better equipped to give due weight to the interests of the community: these are the crucial questions raised by the view of $\mathrm{Mr}$. Chief Justice Hughes. Mere opinions, from whatever sources they emanate, cannot resolve these issues. Of opinions there have been more than enough $;^{\mathbf{1 4 2}}$ of evidence only a little. Gradually, however, a literature of administrative law which reveals the actual workings of administrative agencies is being built up. ${ }^{143}$ It is not too much to hope that the increasing devotion of effort and money to research in this field will produce a better understanding of what is taking place and will result in the adjustment of legislative and judicial policies to the need for efficient, fair administration. ${ }^{144}$

141. 285 U. S. at 57.

142 Much has been made of the "combination of prosecutor and judge" which cxists in many administrative agencies. CoMmittee on MINisters' Powers, Report (1932) at 78 , suggesting that service of the public interest by an official may be more destructive of impartiality than the involvement of self-interest, since it may be unrestrained by conscientiousness; 61 A. B. A. REPORT (1936) at 732-736. To this contention the reply is made that judicial zeal in behalf of private as against public interest is at least as warping in its effects. Perhaps the best summary, albeit somewhat idealized, of the respective qualities of judicial and administrative determining processes is contained in Robson, Justice and Administrative Law (1928).

143. See c.g., Pattersox, The Insurance Commissioner in the United States (1927); Henderson, The Federai Trade Commission (1924); Sharfman, Tile Interstate CoMrmerce CoMmission (5 vols., 1931-1937); Dodd. Administration of WORKMIEN'S COMPENSATION (1936); surveys of deportation administration, cited supra note 128; Brown, The Administration of Workmen's Compensation in Wis's." (1935) 10 Wis. L. REv. 345; McClintock, The Administrative Determination of Public Land Controzersies (1925) 9 MINx. L. Rev. 638; Hyneman, The Case Law of the New York Public Scrice Commission (1934) 34 Coz. L. REv. 67; Garrison, The National Raiiroad Adjistment Board (1937) 46 Yale L. J. 567; Cosier, Legislative Functions of Nitional Admisistrative Acthorities (1927) cc. vii, viii; Wheat, The Railroad Commission of California (1927) 15 CALIF. L. REv. 445. As to the personnel of the independent Federal commissions see Herring, Federat Commissioners (1936).

144. The threat presented by the Supreme Court cases on judicial review may not materialize, and the effects of the distrust of acministrative authority which it expresses 
Legislative remedies lie, in the first place, in improving the personnel of administrative agencies so as to minimize the need for review of administrative determinations. In some matters nothing more seems necessary. Whether an animal is diseased and hence subject to destruction in order to prevent the spread of the disease is a matter which may as well be determined once and for all by a competent expert, subject to the assumption of liability by the state if a claims tribunal finds that an error has been made. Where human interests are more directly involved, as in the determination of insanity and of the need for asexualization, a tribunal should be set up with a lawyer, mindful of standards of fair procedure, as one of its members, or judicial review of essential procedural points should be provided, or both safeguards should be afforded. Where more judgment and les's cold fact are involved in a decision, some review of the initial determination probably is wise, if only to satisfy the natural feeling of those adversely affected. The tendency among students of administrative law in this connection, is to advocate administrative tribunals with broad reviewing powers, to precede or supplant the courts as reviewing agencies. ${ }^{140}$ The principal questions involved in the proposal are, first, whether there should be a single set of such tribunals with inclusive jurisdiction, as in France, or a number of specialized tribunals and, second, how much of the field of administration should be subjected to their control.

In the Federal system in the United States, specialized appellate tribunals such as the Customs Court, have been established in a number of fields of administration. ${ }^{146}$ These are not courts in the full sense and

may be mitigated, by reason both of changing personnel upon the court and the opportunity for a new doctrinal start which is presented by recent legislation. The rourts are now directed, in case the presentation of additional evidence should be permitted following an appeal from an administrative order (reasonable ground for the failure to adduce it earlier having been shown), to remand the case for the taking of such evidence and, if necessary, the modification of the order. Bituminous Coal Act (1937) $\S \S 6($ b), (c), 50 Stat. 85,15 U. S. C. A. $\$ \S 836(b)$, (c) (Supp. 1937) ; National Labor Relations Act (1935) $\S \S 10(\mathrm{e}),(f), 49$ STAт. 453, 29 C. S. C. A. $\$ \S 169$ (e), (f) (Supp. 1937) ; Public Utility Folding Company Act (1935) §24, 49 STat. 834, 15 U. S. C. A. $\$ 79(x)$ (Supp. 1937) ; Securities Excinange Act (1934) $\$ 25,48$ STAт. 50, 15 U. S. C. A. $\$ 78(y)$ (Supp. 1937).

145. Hart, The President and Federal Adninistration, in volume of essays cited op. cit. supra note 3, at 92; Wade \& Phillips, Cosstitctional Law (2d ed., 1935) at 99 ; Jennings, loc. cit. supra note 122 ; Willis, of. cit. supra.note 20 , at $59-60$; A:sER. Bar Assoctatior, Report of Special Consuittee os Adsinistrative LaW (1936) 61 A. B. A. REF. 720.

146. Customs Court, 46 Stat. 730,737 (1930), 19 C. S. C. A. $\$ \$ 1501,1518$ (1934); Board of Patent Appeals, 44 Stat. 1336 (1927), 35 U. S. C. A. $\$ 57$ (1934); Court of Customs and Patent Appeals, 45 STAт. 1476 (1929), 35 U. S. C. A. \$59(a) (1934), 28 U. S. C. A. $\S 303($ a) (1934); 45 STAT. 762 (1930), 28 U. S. C. A. $\$ \$ 301(a), 303$ (1934); Board of Tax Appeals, 44 Stat. 105 (1926), 26 U. S. C. A. $\S 6$ fo ff (1934). 
may be composed partly of officials who have had administrative experience. They may review both the law and the facts, and thus are able to penetrate to the heart of the controversies involved and to render informed decisions. Their work seems to have met with general approval. It has been proposed both that reviewing tribunals be set up in other Federal agencies which make decisions affecting private interests ${ }^{147}$ and that the existing tribunals be consolidated into a Federal administrative court whose jurisdiction shall be extended from time to time over additional "judicial" determinations of the Government's administrative agencies. ${ }^{148}$ It does not follow from the success of the present tribunals, however, that similar bodies are necessary or would operate successfully in all other fields of administration; and it is possible that a consolidated administrative court would lack the expertness of the existing bodies in relation to the matters coming before it. ${ }^{149}$ Its attitude might become too largely detached and "judicial," or even hostile. At least one ill-fated experiment, the Commerce Court, has shown the harmful effect of review by a specialized tribunal whose attitude was of this variety - although it is probable that the difficulty in the particular instance lay partly in current political conditions and in a combination of specialization, limited scope of review, and strictly judicial methods and personnel. ${ }^{150}$

The course of wisdom is to introduce appellate administrative tribunals into particular fields of administration as their presence is shown to be needed, ${ }^{151}$ taking care that they have the characteristics of both expertness and fairness, rather than to attempt to legislate at one fell swoop for the entire executive branch of the Federal Government. At the same time the effort should be made to restrict the review of their determinations by the regular courts as fully as the legal competence of their membership, ${ }^{152}$ the need of unity in the adminstrative system, and the

147. Op. cit. supra note 76, at 170-172, 199 ff., 225-228.

148. American Bar Association, Report of Spectal. Committee on Administrative LAw (1936) 61 A. B. A. REP. 720. This propusal has now yielded to the one previously mentioned. Op. cit. supra note 76 , at 184 .

149. The American Bar Association Committee, however, contemplated a court which should be divided into sections with specialized functions. REPoRT (1936) 61 A. B. A. ReP. 720 , at 745 .

150. See Frankfurter \& Landis, The Business of the Suprease Court (1928) at $153-174$.

151. See the recommendation of the National Commission on Law Otservance and Law Enforcement with respect to the Immigration Service of the Department of Labor, in loc. cit. supra note 128; Oppenheimer, Recent Developments in the Deportation Process (1938) 36 Mich. L. REv. 355.

152. There is little indication in the literature of a disposition to dispense with legal competence in the conduct of administration. The lawyer in administration is essentially an expert in procedure, and there is need for his services wherever governmental processes, making use of sanctions, are employed. FREUND, Legislative Regulation (1932) at 114. 
state of constitutional doctrine will allow. Consolidation of tribunals, or extension of their jurisdiction, can then take place as expediency dictates, after the manner of the formation of the present Court of Customs and Patent Appeals. ${ }^{153}$

Proposals of a sweeping character for the establishment of appellate administrative tribunals encounter the difficulty of defining in general terms the type of administrative determination to be reviewed. For this purpose the terms "judicial" or "quasi-judicial" are commonly employed. Their lack of precision has been amply demonstrated. ${ }^{153}$ In an apparent attempt to avoid such ambiguity, the latest recommendation of the American Bar Association's Special Committee on Administrative Law, which calls for administrative appeal boards in many federal agencies, would confer power to review any "decision, act, or failure to act" whereby any person "is aggrieved." 105 An appeal would lie from the appeal boards to the Circuit Courts of Appeal. The apparent effect would be to compel "quasi-judicial" procedure whenever someone asserted a grievance in the prescribed manner.

\section{The Formulation and Effectuation of Policy through Administration}

As an accompaniment to the discussion of the "rule of law" in English administrative law literature, there is a recognition of "ministerial responsibility" as a fundamental principle to which effect must be given so far as possible. ${ }^{156}$ This responsibility assumes two aspects: first, control by department heads over their subordinates, and second, answerability by the former to Parliament. The English system of regulatory and welfare administration began with commissions created by, and reporting directly to, Parliament. ${ }^{157}$ It has evolved into a system of

153. 45 Stat. 1475 (1929).

154. Cooper, The Proposed United States Administratize Court, Part II (1937) 35 Mícr. L. Rev. 565; Hyneman, Administratize Adjudication: An Analysis (1936) 51 PoI. ScI. Q. 383; O'Reilly, lnc. cit. stipra note 26. Professor William A. Robson made a gallant attempt to define the content of these terms before the Committce on Ministers' Powers, but it broke down completely. Mrrutes of Evionice (1932) at 63 ff., 81 ff.

155. REPORT, op. cit. supra nate 76 , at 225 .

156. Even the advocates of imposing additional controls upon the evercise of discretionary powers by the departments concede that these should not tie the minister's hands in matters in which he is responsible to Parliament. Cussasurtee o:i Mrmisteps' Powers, Mrsictes of Endoesce (1932) at 100 (testimony of Mrr. H. A. Hill). See also the testimony of Sir Maurice L. Gwyer. Id., at 31. The procedure of laying administrative rules before Parliament for a period of time before they become effective [see supra p. 560 ] is a recognition of "responsibility" as well as of the legislative character of the rules. Its effectiveness is a matter of dispute. Id., at 45 (testimony of Sir Nilliam Graham-Harrison; Id., at 123 (testimony of Sir Arthur Robinson and Mr. E. J. Maude).

157. Anderson, Bureaucracy (1929) 7 J. PuB Adarrs. 3, at 9; Wruss, op. cit. supro note 14 , at 17 . 
single-headed departments, ${ }^{158}$ with occasional boards performing specific functions. ${ }^{15 \dot{\theta}}$ The minister in charge of each department has complete authority over it. Answerability to Parliament is by the ministers collectively through the Cabinet and by each minister personally through his subjection to interrogation on the floor of Parliament by the members. The latter device for securing "responsibility" furnishes the most available political check upon departmental acts affecting private persons and property; for it is not difficult for an aggrieved constituent to have his grievance made the subject of questioning by the member who represents him in the House of Commons.

Interrogation furnishes, to some extent, an alternative to judicial review as a safeguard to the interests that are affected by administration. ${ }^{160}$ It operates through the channel by which policy is transmitted from its source in the legislature to the point at which it finally results in official action. Thus it conforms to a concept of efficiency in administration which is central in modern political-science theory. That concept requires the continuous control of administration by the policydetermining agency of the government and means whereby administration is kept in touch with those interests in the community upon which it bears. The latter element will be considered first.

The maintenance of contact with affected interests in administration occurs both in connection with rule-making and in the process of making decisions. In the former it is accomplished largely through consultation with these interests; in the latter through the device of notice and hearing. In so far as these devices are effective, and in so far as the initial formulation of policy by the legislature is accomplished with due participation by all recognized interests, the need of an external check upon administration, at the hands of the courts or otherwise, is diminished. ${ }^{101}$ The formulation of policy by the legislature is beyond the scope of this paper. The matter of notice and hearing in connection with administrative decisions has been extensively treated in the literature. ${ }^{102}$ The device of consultation should, however, be noticed briefly here.

158. Even the Board of Trade, in whose name vast functions are carried on, is in effect a mythical body. It never meets, and the department which it controls in name is in reality a ministry which is headed by the President.

159. Anderson, loc. cit. supra note 157. There is a recent tendency to set up special boards, or authorities, for the conduct of economic schemes under governnent auspices. See Elliot, loc. cit. sipra note 113.

160. One of the grounds of decision in the famous Arlidge case [(1915) A. C. 120] was that the officials of the Local Government Board might properly be allowed some freedom in the procedure by which they determined the unsuitability of the petitioner's building for human habitation, because they were answerable in Parliament for what they did.

161. Gaus, The Responsibility of Public Administration in Gavs, WhIte \& Dnuocr, The Frontiers of Public Administration (1936) at 37.

162. See the authorities cited supro, note 131 . 
In England the consultation of affected interests by the government departments entrusted with rule-making functions has become a recognized practice that is almost uniformly followed. ${ }^{103}$ Of necessity, the methods by which this consultation is effected vary with the forms of group organization with which the ministry is confronted; and there are important unorganized interests which the ministry itself must, in a sense, represent. ${ }^{164}$ But the practice appears to have been largely successful. Under it the citizen is not "treated as an inert subject or as an aggressive person eager to outwit the law or obtain some special advantage." $165 \mathrm{He}$, or his group, is treated as a rightful participant in administration; and the resulting governmental measures, which take account of his needs and his wishes, are much more likely to meet with his approval than would otherwise be the case. These consultative means have thus effected "an extension of representative government . . . in the course of the last century." 160

Although no such uniformity in the practice of consultation has grown up in the United States, the constant stream of conferences between governmental agencies and business interests indicates that the device is frequently resorted to. ${ }^{167}$ Somewhat anomalous is the Federal Trade Commission's trade practice conference procedure. No official action. results from it; yet understandings of the highest importance are reached with trade and industrial groups in regard to future competitive practices. ${ }^{168}$

More formal in character are the advisory committees attached to various administrative agencies for the purpose of reflecting the opinion of affected interests and of interpreting official action to those interests. ${ }^{100}$

163. Carr, Decegated Legislation (1921) at 31-32; Burns, Governzrent and

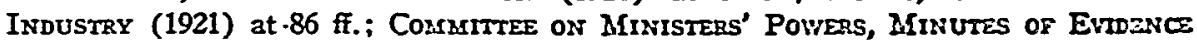
(1932) at 5 (testimony of Sir Maurice L. Gwyer); Id., at 120 (Supplementary Mfemo. of the Ministry of Health); Wade, Departmental Legislation (1933) 5 CAssd. I. J. 77, at 81; 2 Axson, Law and Costom of tee Constitution (4th ed. by Keith, 1935) at 256.

164. See Conmittee ox Ministers' Powers, Minutes of Enidence (1932) at 120 (Supplementary Memo. from the Ministry of Health).

165. Gaus, $A$ Theory of Organization in Public Administration, in GAus, Wnite \& Drsock, op. cit. supra note 161, at 88. See also Laskr, Grazszar of Poumics (1925) at 244 ff. For a thorough account of American experience and its significance see Herrisg, Public Administration and the Public Interest (1936).

166. Suggestion of Sir Leslie Scott, member of the Committee on Ministers' Powers. Minutes of Entdence (1932) at 130.

167. COMER, op. cit. supra note 143, cc. 7,8 .

168. See Oppenhein, Cases on Trade Regulation (1936) at 1305.

169. Machinery of Goiernuent Cousurttee of the [British] Ministry of Reco:STRLCTION (1918) at 11-12; MIUIR, How Britain Is Gover:Jed (1929) at 300 ff.; Fairlie, Advisory Committees in British Adminislration (1926) 20 Ass. Pol. Scr. Rev. 812; Willis, op. cit. supra note 14, at 36-37; McMiahon, Boards, Advisory (1930), 2 ENCYC. SOC. ScIENCES 609. 
More direct participation of groups in administration results from the presence of group representatives upon official agencies. ${ }^{170}$ The delegation of official power to private groups ${ }^{171}$ carries the evolution to an ultimate conclusion. ${ }^{172}$ The conclusion, however, is one that divorces public officials from the administrative process which formerly they monopolized. Absent an effective governmental direction of the activity of these private groups, the ideal of a direct, purified transmission of policy from its responsible source to its execution is completely lost. ${ }^{173}$

In the United States there is of necessity a greater divorcement than in England of policy determination from the exercise of continuous controlling powers over administration. Since the executive occupies a constitutionally independent position, there is no doctrine of general administrative responsibility to the legislature. ${ }^{174}$ There can be, however, and of late there has been, a strong iendency to increase responsibility of all administrative agencies to a single executive head. ${ }^{175}$ That tendency has now reached the point of attacking the continued existence of the "independent" commissions, whose exercise of regulatory power over economic activity has been one of the most pronounced features of the development of American administration, especially in the Federal system. ${ }^{178}$ The recent withdrawal by the Supreme Court of the constitutional basis for Presidential removal of the members of these commissions ${ }^{177}$ has eliminated the sole means of former executive control over them except the exercise of the power of appointment to vacancies, after terms of office which exceed the President's own.

The attack upon the independent commissions for the purpose of strengthening the executive is reinforced by two other ideas: first, a

170. Chamberlain, Democratic Control of Administration (1927) 13 A. B. A. J. 186.

171. Comment (1932) 32 CoL. L. Rev. 80; Comment (1937) 37 CoL. L. Rev. 447; Jaffe, Law Making by Private Groups (1937) 51 Harv. L. REv. 201.

172. In England, delegation to professional organizations "need occasion no remark", for "gild-like organizations have supervised trade from time immemorial." Cars, op. cit. supra note 163 , at 9.

173. See Carter v. Carter Coal Co., 298 U. S. 238 (1936).

174. See White, Introduction to the Study of Public Adrinistration (1926), at $24-30,421-439$, for a summary of the actual extent of administrative responsibility to the legislature in the United States.

175. "In America . . there has emerged in recent years a pronounced tendency to enhance the administrative powers of chief executives, including the president, governors, mayors, and managers." White, Administration, Public, 1 ENcyc. Soc. Scrences (1930) at 449. On the strengthening of the Presidency, as a fact and as a desirable policy, see Hart, The President and Federal Administration in the Goodnow Essays, cited supra note 3. See also WHITE, op. cit. supra note 174, at cc. v. and vi.

176. President's Comamtitee on Aduinistrative Managersent, Report (1937) Part I, at $31 \mathrm{ff}$.

177. Rathbun v. United States, 295 U. S. 602 (1935). See Donovan \& Irvine, The President's Power to Remove Members of Administrative Agencies (1936) 21 CORN. L. Q. 215. 
belief in the superiority of the single-headed department as an administrative mechanism ${ }^{178}$ and second, dissatisfaction with the commingling of "quasi-judicial" and administrative functions in the same agencies. ${ }^{170}$ It is unnecessary to discuss these reasons separately here, but points relating to them will appear incidentally. ${ }^{180}$

The President's Committee on Administrative Management uses strong language in condemning the presence of the "independent" commissions in the government. ${ }^{181}$ The meat of the matter appears in the statement that "there has grown up a headless 'fourth branch' of the government, responsible to no one, and impossible of coordination with the general policies and work of the government as determined by the people through their duly elected representatives." 182 This view is based upon current political-science conceptualism, which assumes that all policies should respond to the verdict of the last election. Probably most policies should. But there is evidence that certain policies should be controlled by somewhat slower processes. Statutory or constitutional tax levies, alterable only by vote of the people, are the foundations upon which many public educational enterprises rest, and they do not necessarily cut too deeply into current budgetary administration. For different reasons, some governmental economic policies, involving the weighing of interrelated interests ${ }^{183}$ and the careful estimation of the effects of governmental measures and constituting the framework upon which private enterprise must build, ought to be entrusted to long-time formulation under expert control. It is not without significance that lawyer ${ }^{184}$ and economist ${ }^{185}$ unite in sustaining the wisdom of maintaining independent commissions in the field of economic regulation. Hov far governmental economic

178. "Boards make screens. If anything goes wrong, you don't lnow where to find the offender; it was the board that did it, not one of the members; always the boord, the board!" Bentham, quoted from Richard Rush in OGDeN, Jeneary Benrinas, 18322032 (1932) (appendix). See also Lrser, Grazraras of Pourtes (1925) at 370;

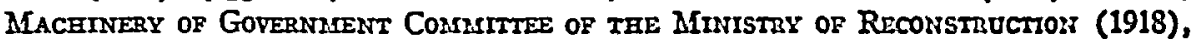
at 11.

179. Ajrerican Bar Assoctation, Report of the Spectal Condutiter on AdumnisTRATIVE LAw (1934) 59 A. B. A. Rep. at 540, 544, 551.

180. The effect of mingling administrative and judicial functions (the "prosecutorjudge" combination) has been mentioned supra, $n, 142$.

181. REPORT, op. cit. supra note 176 , at 32.

182. Ibid.

183. Mansfield, The Hoch-Smith Resolution and the Consideration of Commercial Conditions in Rate Firing (1931) 16 ConN. L. Q. 339; 1 Senrfanar, Tue Intenstate Comarerce Counussion (1931) 225-235; $3 \mathrm{~B}$, id., at 413-463.

184. Robinson, The Hoch-Smith Resolution and the Future of the Intcrstote Commerce Commission (1929) 42 Harv. L. Rev. 610; Hendenson, Tge Fenerar Trade Commission (1924), at 341. See also Eastman, The Place of the Indefendent Commission (1928) 12 CoNst. REv. 95, at 100.

185. Sharfacan, op. cit. supra note 2 , at 952-953. 
planning can be extended and stabilized no one can yet say; but there seems to be no adequate reason for destroying the results that have been obtained. Congressional alteration of fundamental policy will always be possible.

The matter of stabilized economic control by independent commissions must be deçided, of course, in regard to each one separately. The report of Professor Cushman, upon which the recommendations of the President's Committee presumably are based, enumerates some matters that should be subject to Presidential control and, therefore, to changes of policy with changing administrations or with successive Presidential expedients. Among these are the balancing of interests in railroad ratemaking policy and the attitude of the government in the enforcement of the anti-trust laws. ${ }^{188}$ The proposal requires further study by economists to ascertain whether the economic system can survive control of the suggested variety.

But the conflict between the President's Committee and the advocates of independent commissions is not so irreconcilable as it may seem. For within the departments to which these agencies would be transferred under the Committee's proposal there are to be autonomous "judicial sections," to which the deciding of cases would be entrusted after the administrative section had duly formulated the policies. "The division of work between the two sections would be relatively simple." 187 The administrative section, it is said, would only prepare cases as the examiners of the Interstate Commerce Commission and the Federal Trade Commission now do. It does not appear at this point what would become of the President's control of the policies that in the end decide the cases, if the judicial sections did the deciding.

It is impossible here to enter upon a detailed critique of the feasibility of this proposal to segregate the "judicial" from the "administrative" functions of the independent commissions. Professor Cushman is clear in his own mind that if the divorce cannot be effected, the independent commissions should be retained. ${ }^{188}$ Perhaps the Committee thinks likewise. In any event, advocates of the contending viewpoints can meet upon the common ground of ascertaining the practicability of the proposal in the light of agreed objectives. Similar meeting of minds might be achieved in regard to the Committee's ${ }^{180}$ and Professor Cushman's ${ }^{100}$ objection to the mingling of administrative and judicial functions. The objection is based upon the danger of the "prosecutor-judge" combina-

186. Report of the President's Committee (1937) Part II, at 220-221.

187. Id., Part I, at 41 .

188. Id., Part II, at 219.

189. Id., Part I, at 40 .

190. Id., Part II, at 222-223. 
tion. The reality of the danger and the merits of the alternative plan are not undiscoverable. No one wants to mow down private interests ruthlessly on the. one hand or to protect them at all costs on the other, and the need of administrative powers is everywhere recognized. The chairman of the American Bar Association's Committee on Administrative Law is as emphatic as the President's Committee in recognizing the legitimacy of the people's demand for a distribution of welfare commensurate with the technological state to which we have attained. ${ }^{101}$ The latter Committee is solicitous of impa.tial administrative adjudication no less than of effective administrative management.

\section{The Reality of Agreensent within Denocracy}

It would be naive to suppose that verbal agreement upon broad objectives in itself constitutes an effective coming together of opposing points of view with reference to administrative law and administrative organization. Proponents of strong government and believers in the greatest -possible opportunity for private interests to employ remedies against administrative action are apparently in present agreement upon the absorption of the independent commissions into executive departments of the Government and upon the need for separating "administrative" and "quasi-judicial" functions. but in view of the ambiguities which lurk behind their words, they are all too likely to fly apart. Nor is it certain, when -adherence to the ideal of distributed welfare is expressed on the one hand by believers in concentrated executive power and on the other hand by supporters of simplicity in government, that they would permit the ideal to prevail over the chosen means of attaining it, if there should be any incompatibility between the two. But it is something to have the objectives stated, with the explicit rccognition that the means are subordinate to them. and it is equally encouraging to have it announced that proposals for specific change are intended for acceptance only if the feasibility of their execution can be demonstrated.

The Report of the Committee on Ministers' Powers in England, despite shortcoming $\equiv$ in its conceptual approach, has cleared the atmosphere and leit twr principal issues for solution: (1) the extent to which. if at all. legally uncontrolled administrative rule-making powers should be cronierred in legislation and (2) the length to which the courts should be permitted tos gro in quashing administrätive rules and decisions

191. 3ICGripe, The Fevepal Aumisistrative Service and the People of the United STATE (1937) at 2. The Association's committee has wisely chosen to limit its studies and recemmendations to matters of procedure, recognizing that it would be neither prsssible tro stem nror pertinent to the lawyer's function to pass judgment upon the prolicy $r i$ increasing resrort to administrative control. (1933) 58 A. B. A. REPORT 407 ; (1934) $39 \mathrm{Id}$., at 543. 
because of alleged illegality in the administrative procedure which led to them. In the United States, even in the Federal system taken by itself, the issues are slightly more complex and their solution lies with the Supreme Court as well as with Congress; but they have been defined with striking effect by men who adhere to the democratic ideal.

In the meanwhile, the materials in terms of which the accepted answers must be cast are slowly accumulating. Not only are the operations of particular administrative agencies and types of administrative action being revealed with thoroughness, but the processes of administrative effectuation of policy are being analyzed in terms that may lead to practical solutions of such problems as that of the maximum supervisory load which a chief executive can bear. ${ }^{192}$

At least in the presence of accepted ultimate purposes, such as those involved in the democratic thesis, some approach to a scientific choice of means seems possible. ${ }^{193}$ "Within broad limits, governments both here and abroad are now attempting to manage the whole economic system in the interest of individual security, rather than to supervise a small section in the interest of free competition." 104 They cannot escape from the task or from maintaining administrative systems adequate to its performance. We must learn, as quickly as we may, how to make popular government at once responsible, capable, and just. ${ }^{105}$

192. Involved in this problem are the "span of attention" which is psychologically possible and the types of "line" and "staff" organization which will add to the possible "span of control." Gaus, A Theory of Organization in Public Administration, in GuUs, Wrire, \& Drsock, op. cit. supra note 161.

193. White, The Meaning of Principles in Public Administration, in Gaus, Wh1re \& Druocr, op. cit. supra note 161; Cohen, On Absolutions in Legal Thought (1936) 84 U. OF PA. L. REv. 681, at 703, 715.

194. Leonard D. White, quoted in Remington, Purposes of the Institute of Public Administration (1936) 14 J. PUB. ADssiv. 30.

195. Cf. Green, The Administrative Process (1935) 21 A. B. A. J. 708. 